\title{
O CORPO DANADO
}

\author{
Sergio Rizo ${ }^{1}$
}

\section{Resumo}

A representação do corpo humano tem sido um tema central na arte ocidental. Em consonância com esta tradição e desde os seus primórdios, o cristianismo utilizou um sistema de representações com base no corpo humano que enfatizou a relação problemática entre o corpo e a alma. A ambiguidade do corpo cristão dividido entre as forças do bem e do mal, premido entre o Paraíso e Inferno, deu origem a uma vasta produção de representações e metáforas relacionadas ao corpo humano na história das artes visuais e literárias.

O foco principal deste artigo é a maneira pela qual os corpos nus dos condenados são representados e relacionados com os corpos demoníacos no tema maior do Juízo Final e da sua categoria dependente, ou seja, a do Inferno. Uma história das representações do corpo nas imagens do Inferno feita a partir de uma concepção teocêntrica e medieval do mundo, que concebeu um corpo miserável em oposição à alma divina, e que vai ao humanismo contagioso da Renascença, quando as representações do corpo humano no Inferno, às vezes eróticas, eram de fato belas, devido à influência da Antiguidade e aos novos estudos sobre anatomia humana, elaborados pelos seus artistas.

\section{Palavras-chave:}

Corpo Danado, Nudez, Anatomia, Juízo Final, Inferno, Arte Medieval e Renascentista.

\footnotetext{
${ }^{1}$ Sergio Rizo possui graduação em Arquitetura e Urbanismo pela Universidade de Brasília (1979), mestrado em Fine Arts - Pratt Institute (1990), New York, como bolsista do Conselho Nacional de Desenvolvimento Científico e Tecnológico, $\mathrm{CNPq}$ e Doutorado em História pela Universidade de Brasília (2004). Professor da Faculdade de Arquitetura e Urbanismo da Universidade de Brasília, desde 2012, lecionou no Departamento de Artes Visuais/ Instituto de Artes da Universidade de Brasília de 1991 até 2012. Tem experiência na área de Artes, com ênfase em Pintura, Desenho e Teoria e História da Arte.
} 


\begin{abstract}
The representation of the human body has always played a central role in Western art. In line with this tradition and since its beginning Christianity has used a system of representations oriented around the human body to emphasize the problematic relationship between the physical body and the soul in contrast with the idealized body of the Greek and Roman Classical Antiquity. The ambiguity of a Christian body fought over by the opposing forces of good and evil, wrenched between Heaven and Hell, gave origin to a vast number of representations and metaphors relating to the human body throughout the history of the written and visual arts.

The main focus of this article is on the manner in which the nude bodies of the damned are represented and related to the demonic bodies within the Last Judgment theme and its dependent category of Hell. A history of the body representations in the images of Hell starting from a medieval theocentric conception of the world, which conceived a miserable body as opposed to the divine soul, to the contagious humanism of the Renaissance, when the representations of the human body in Hell, sometimes eroticized, were in fact beautiful due to the influence of Antiquity and the new studies on human anatomy by the artists.
\end{abstract}

Keywords: Damned Body, Nudity, Anatomy, Last Judgment, Hell, Medieval and Renaissance Art. 


\section{O CORPO NU: O EROTISMO NO INFERNO}

A Antiguidade greco-romana tinha por preceito de arte a harmonia das relações entre a mente e o corpo, traduzidas por musculosas estátuas nuas, moldadas em faces e expressões inteligentes, atestando estreita relação entre ação muscular e pensamento. Havia um anseio idealizado da integração do corpo e da alma que se evidenciava na expressão latina mens sana in corpore sano. "A perfeição do corpo e da mente é relativa aos deuses"2, diz Arnheim no seu ensaio sobre a perfeição divina, e aos gregos, coube imitá-la.

Na Idade Média o corpo e a sexualidade eram tidos como expressão do pecado e, assim, os conceitos religiosos enfatizavam a elevação do poder espiritual e mental, abstraindo-se das ações expressivas do corpo. A alma como espírito permanente seria muito valorizada; o corpo tornou-se seu hospedeiro e servo; no corpo estaria a origem das paixões e vícios de toda sorte. Contrariamente aos gregos e romanos, o cristianismo se insurgiu contra a carne. Toda a ascese cristã teve milenarmente como finalidade a mortificação da carne, controlando e sujeitando o corpo pelo espírito. A carne viva, pulsante, orgânica, que abriga as emoções humanas, material na sua própria existência, com suas necessidades físicas, seus desejos, seus impulsos sexuais e suas contradições espirituais, é que será o objeto central da tentação satânica. Para tanto vale perguntar Qual é a fonte do desejo carnal? O corpo. Qual é a entrada do desejo carnal, da tentação diabólica? O corpo, por meio dos sentidos da carne. Como e onde se dá o pecado? Com a ação do corpo nele mesmo ou em outro corpo. Portanto, o suplício do pecado se dá no corpo.

As representações do Inferno com seus corpos supliciados reforçam a ameaça da punição do Além e Satã é, ao mesmo tempo, o instrumento da sedução, a indução do pecado e o agente da punição eterna.

A representação do suplício do corpo humano no Inferno era fundamental na arte cristã enquanto de uso educativo pelo clero. A igreja, a partir do séc. XII utilizou sistematicamente a representação do corpo como o objeto exemplar da punição infernal. Dante, por exemplo, como homem profundamente religioso, seguiu esta tradição ao enfatizar a imagem do corpo punido na sua visão do Inferno. E a permanência das representações dos suplícios infernais é de tal ordem que o corpo no Inferno, por exemplo,

\footnotetext{
2 ARNHEIM, Rudolf. No artigo intitulado A Perfeição de um Deus. In ARNHEIM, Rudolf. The Split and the Structure: Twenty Essays, p. 83. University of California Press, 1996.
} 
foi a maior referência nas ilustrações que o artista francês, Gustave Doré, fez da Divina Comédia de Dante em pleno século XIX. Na série de gravuras, por sinal, pode-se claramente perceber uma acentuada influência de Michelangelo nos desenhos dos corpos humanos. A ênfase na anatomia, o páthos característico na posição corporal dos danados e a sua monumental expressão conformam, em termos iconográficos, uma continuidade evidente do fatum renascentista. De fato, trata-se de uma atualização do fin-de-siècle da representação do Inferno, tanto no caráter iconográfico, referente a uma concepção temática medieval, quanto no formal, relativo a uma prática de arte vigente no Renascimento, e que permaneceu orientada para o aspecto típico da secular moralidade cristã de castigar o corpo pecador.

A questão da representação do corpo no cristianismo delineou-se particularmente problemática quando houve a necessidade de mostrar a nudez em certos temas da sua iconografia. A iconoclastia do judaísmo, presente no cristianismo primitivo, resultou na condenação da fabricação de imagens humanas que fossem contrárias ao segundo mandamento ${ }^{3}$. Os ídolos pagãos eram especialmente perigosos porque representavam, além dos aspectos profanos, "a morada dos demônios, que astutamente assumiam formas e nomes de seres humanos belos" $" 4$ (CLARK, 1956). A nudez então, ficou por muito tempo associada ao diabólico. Na tradição medieval, a nudez era uma fonte de vergonha e na vida real os criminosos eram desnudados como punição aos seus crimes.

A nudez no Inferno também possui uma conotação de ordem simbólica que é oposta ao corpo vestido. No pensamento de Hollander (1978), a uma conceituação do significado do corpo nu deve-se sempre levar em conta o corpo vestido. A representação da figura humana clássica, no mundo greco-romano, era composta de uma unidade natural que integrava o corpo e a vestimenta, unificada que estava pelo princípio da beleza e pelo amor da geometria e proporção. Na Idade Média, o equilíbrio entre a vestimenta e o corpo foi desfeito para ocultar uma nudez que veio a ser considerada vergonhosa, acentuando a distância entre o corpo e a veste. O gosto medieval compensou o seu desprezo pelo nu com um apego significativo ao caráter enobrecedor das vestimentas, que passaram a ser representadas em todas as suas formas e coloridos no panejamento exemplar das

\footnotetext{
3 O segundo mandamento consta no Êxodo $(20,4-6)$ e diz: "Não farás para ti imagem de escultura, nem figura alguma de tudo o que há em cima do ceu, e do que há em baixo da terra, nem de coisa, que haja nas águas debaixo da terra. Não as adorarás, nem lhes darás culto (...)’in: Bíblia Sagrada, Edição Barsa, 1965.

${ }^{4}$ CLARK, Kenneth. $\mathrm{O} N u$, Um Estudo sobre o Ideal em Arte, Lisboa, Editora Ulissea, 1956. p.244.
} 
iluminuras e pinturas medievais. "A natureza do homem e a natureza da vestimenta não são mais consideradas como originárias da mesma fonte" ${ }^{, 5}$ as vestimentas se tornam o glorioso símbolo da pureza e a instância superior do divino. As vestes não eram sujeitas ao pecado da carne, o corpo sim.

Houve então, no início da Idade Média, uma patética mudança na condição do corpo nu, que na arte clássica grega era heróico e belo, orgulhoso, reflexo do divino, e que passa a ser vergonhoso, humilhado, miserável e reflexo do terreno na arte cristã. Das origens atléticas da palestra onde o corpo heróico ostentava-se orgulhosamente, "o nu cristão começou com o corpo encurvando-se ao tomar consciência do pecado" ${ }^{\prime 6}$ (HOLLANDER, 1978). De uma postura geral convexa do corpo passou-se a uma côncava. Do corpo aberto em arco e flecha pronto para o arremesso as alturas do céu, fez-se o corpo fechado, tornado ao chão.Transpôs-se visualmente, o dogma da culpa cristã nessas representações corporais de curvas enfunadas, voltadas para si, envergonhadas não só da sua nudez como também da sua própria existência física.

O fechamento do corpo vexado e nu nas representações da arte cristã a partir do século X corresponde aos temas do Pecado Original, da Expulsão do Paraíso e da Queda dos Anjos Rebeldes ${ }^{7}$. A partir do século XII são frequentes as representações e imaginários referentes ao corpo no Inferno. De tanto olhar para baixo e de curvar-se, o corpo perfurou a superfície da terra e adentrou a região do inferus. A utilização do nu como a iconografia típica do Inferno criou duas novas categorias de corpos, exemplares do funcionamento deste verdadeiro complexo de punições do Além. Os demônios e os danados. Só que no Inferno a concavidade, característica do corpo culpado, é transferida ao corpo supliciado, e ganha um novo significado. O corpo premido pelo peso da culpa e da vergonha é então transformado no corpo punido, é feita a curvatura do desespero, que tem de suportar o peso da pena eterna. A dor e o horror expressos nos corpos dos supliciados nos dão a medida exata dos seus pecados. O corpo no Inferno não tem aí alternativa senão sofrer.

\footnotetext{
5 HOLLANDER, Anne. Seeing Trough Clothes, New York, Penguin Books, 1978, p. 15.

6 Idem, p. 246.

7 Deixei de fora a ressurreição por constituir um conjunto de representações do corpo que, dada a sua natureza temática do corpo belo, mais se refere a um retorno ao classicismo da filosofia humanista grega. Esta passagem bíblica, que se representa plenamente a partir do século XIII, em que os mortos retornam a vida na sua melhor condição física, requer o uso de uma noção do belo, estando mais vinculada ao corpo pagão da herança grecoromana do que ao corpo miserável do cristianismo.
} 
Um dos exemplos mais interessantes de representações de corpos danados no Inferno está no painel do Juízo Final pintado por Rogier Van der Weyden. Este pintor flamengo, uma das vertentes supremas da pintura de Flandres da primeira metade do século XV, realizou uma pintura composta de nove telas de grandes proporções, em comemoração a bula papal de Eugenio VI, que concedeu ao chanceler Rolin autorização para fundar em Beaune um hospital dedicado a Santo Antonio. O painel ficava numa posição superior, na parede de fundo, perpendicular às fileiras dos leitos em que os doentes recebiam atendimento, possibilitando a todos olharem a pintura, mesmo que deitados. O Juízo mostra os danados, nus, a saírem da terra, e após percorrerem um terreno árido, a precipitarem-se num abismo de rochas e chamas. Seus corpos são representados a maneira flamenga, com extrema precisão nos detalhes, particularmente nas expressões faciais. Vêse todo tipo de sentimento de dor estampado nas faces agoniadas dos danados, a culpa desesperada, o remorso mordaz, os olhos esbugalhados próprios desses estados emocionais, línguas para fora, cenhos franzidos e sobrancelhas arqueadas. E muitas bocas abertas, a se lamentar do castigo eterno, ou então aos berros, no preciso momento em que se precipitam no abismo ardente, compondo uma assustadora e dramática sinfonia de gritos e urros de horror. Seus corpos descrevem trajetórias curvas, voltadas sobre si, na medida em que se aproximam do abismo. Lá chegando se arremessam, de cabeça para baixo, às profundezas do Inferno, formando uma alucinada seqüência coreográfica de patéticas e grotescas cambalhotas. O efeito disso tudo é acentuadamente cinematográfico e sonoro, com a pintura figurativa cumprindo uma função representativa bastante abrangente, numa época anterior ao moderno cinema e à fotografia.

Outro ponto importante a ser destacado é a inexistência de demônios a arrastar ou supliciar os danados, indício de um princípio de modernidade nas representações do Inferno. É ao corpo danado que cabe, por meio da expressão da sua culpa e sofrimento, protagonizar, solitário, o Inferno de Van der Weyden.

Kenneth Clark (1956) chega a dizer que o Juízo Final conservou este caráter de um infernal monte de farrapos, até o tempo de Michelangelo, e para tanto cita o exemplo do altar de Danzig, de autoria de Memling ${ }^{8}$, que compara com a obra de Weyden, "em que o quebrado e o desenraizado não têm coesão, mas apenas a tumultuosa e fortuita

\footnotetext{
${ }^{8}$ Hans Memling, pintor alemão que se notabilizou na Flandres e que faleceu em 1494.
} 
angulosidade do acaso"9 (CLARK, 1956) A comparação é justa e oportuna pois que Vasari menciona Memling como “um pupilo de Van der Weyden”, e é inclusive possível que ele tivesse trabalhado no estúdio do mestre até a morte desse. Mas a composição quebrada e confusa dos corpos danados em ambas as obras, mais em Memling, têm a meu ver, do ponto de vista da iconografia do Inferno, toda a razão de ser. Representam o contraponto da organização das fileiras dos corpos abençoados do Paraíso. Deve-se sempre ter em mente de que o Inferno é o lugar do caos e da confusão, em que a folia demoníaca se mostra no maior tumulto, na desordem do reino do Demônio. A tradução visual de tal estado confuso de coisas teria de ser consciente, e até possivelmente sugerida, e não fortuita, pois os pintores flamengos dessa época, eram suficientemente familiarizados com as demandas de ordem simbólica das encomendas dos seus patronos da Igreja.

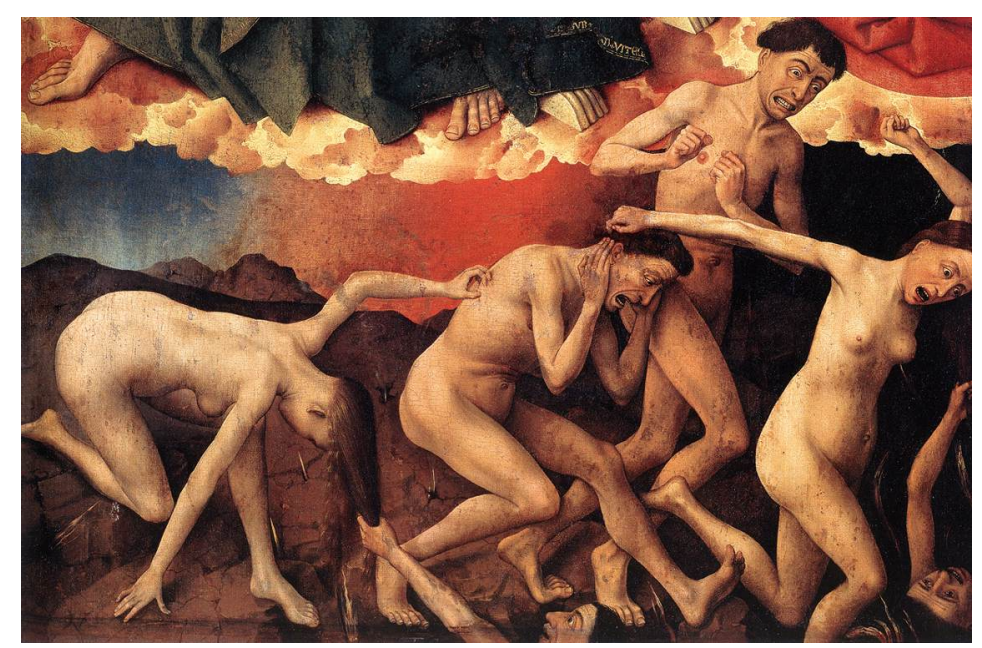

O erotismo no inferno. Van der Weyden, Rogier, Juízo Final e Memling, Hans, Juízo Final

Já os corpos demoníacos, que nos séculos iniciais do cristianismo estavam associados ao perigo da sedução do belo das estátuas pagãs, assumem, a partir do século XII, a forma nua, peluda e monstruosa de uma besta medieval, violenta e sanguinária. Nessa época a Igreja, consoante com o seu programa iconográfico da didática do medo, intensifica o uso das representações do Juízo Final tanto na educação da massa iletrada quanto no combate a heresia. O Inferno, sendo uma iconografia dependente do Juízo Final e o lugar da punição eterna dos pecadores, afirma-se como uma conveniente instância disciplinar da fé. maioria das representações do Inferno, os demônios ocupam-se em torturar, com violência, os

\footnotetext{
${ }^{9}$ CLARK, Kenneth. op., cit, p. 250.
} 
corpos dos danados. Mas em alguns casos, como no Inferno representado por Taddeo di Bartolo $^{10}$, e mais especificamente, no compartimento destinado aos luxuriosos, pude observar figuras de demônios a punir almas danadas de um modo quase que sexual, embora agressivo. Ao invés de sugerir um conteúdo de ordem eminentemente erótica nessas representações, prefiro aventar uma potencialidade sexual e agressiva dos demônios, com uma certa sensualidade, cuja figuração era particularmente problematizada, conforme indicarei a seguir.

A relação a que me refiro é evidenciada pela notável maldade e violência (sadismo seria o termo apropriado somente numa época pós-freudiana) com que os demônios tratam os danados, como na representação mencionada do Inferno de Taddeo di Bartolo ${ }^{11}$. Na sua pintura um demônio peludo com a aparência de um lobo abraça uma alma danada do sexo feminino. Com sua mão esquerda ele simula um gesto carinhoso que na verdade é uma agressão, pois ele arranha a face da mulher com garras afiadas. Enquanto sua mão direita aperta, com lascívia, um dos seios da mulher, seu joelho move-se entre as pernas dela. A boca do demônio lobo está colada à boca da mulher, no que poderia ser uma insinuação de um beijo. Mas na verdade trata-se de uma violação, pois a face da mulher mostra o cenho franzido e uma expressão de pavor estampada nos olhos. Logo atrás consta uma tarja com a palavra adúltera nela inscrita, indicando que esse é o espaço destinado à punição dos luxuriosos. Mas devido à ambigüidade ${ }^{12}$ da cena e frente a uma possível interpretação erótica deste abraço infernal, cabe um esclarecimento.

Para que possa haver um significado de ordem erótica numa representação, é preciso existir uma vontade, uma consciência de atração sexual de uma ou entre as partes envolvidas. Tem de estar presentes um desejo e uma clara busca de prazer, por mais estranhos que possam ser, sem o que resulta absurdo atribuir um sentido erótico a representação. Tem de haver um pacto, de algum tipo sensual, entre as partes. Devo lembrar que o Inferno era o lugar da punição eterna, dos suplícios medievais, e torná-lo um ambiente propício à luxúria (um dos sete pecados capitais), como seria o caso ao se permitir uma inclusão de cenas eróticas (portanto plenas de prazer) na sua representação,

\footnotetext{
${ }^{10}$ Pintor italiano que executou, no final do século XIV, o afresco do Inferno na Igreja da Collegiata, na cidade de San Gimignano, da região de Florença.

${ }^{11}$ LORENZI, Lorenzo. Devils in Art, Florence, from the Middle Ages to the Renaissance. Florença, Centro Di della Edifími srl, 1997. P. 40.

${ }^{12}$ Duplo sentido que creio justificado pois, segundo Freud, os demônios são personificações de maus desejos, recalques e pulsões sexuais angustiantes.
} 
conformaria uma contradição clara aos sagrados mandamentos e plenamente passível de proibição. Não poderia se admitir o uso de imagens eróticas num lugar destinado ao castigo e a dor, e não ao prazer carnal. Há, portanto, de se fazer uma distinção básica entre a relação não biunívoca entre erotismo sensual e agressão sexual, nas representações da arte cristã. A esse respeito, Jérôme Baschet ${ }^{13}$ comenta que na arte, “As características sexuais dos demônios são com freqüência enfatizadas, notadamente quando providos de órgãos sexuais desmesurados e agridem os condenados"14, usando como exemplo mesmo, a representação de Bartolo. Além do que, o Inferno era unilateral, os danados lá se encontravam não por opção, mas por castigo divino dos seus pecados terrenos. Óbvio fica que, se a eles fosse dada uma escolha, lá não estariam.

Antes do Renascimento, o Inferno não era um lugar propício para a representação do erótico. Discordo de George Bataille ${ }^{15}$ em atribuir ao Inferno na Idade Média o lugar específico do erotismo na pintura. Seria admitir toda uma concepção do complexo da dor e do prazer de Sade $^{16}$, pertencente ao século XVIII, numa época principalmente voltada para uma visão teológica da vida e do Além, em que a sexualidade, embora bem mais livre do que se supunha anteriormente ${ }^{17}$, estava em conformidade com a norma religiosa. $\mathrm{O}$ fato é que o público alvo dessas representações, que vivia no século XIV, não tinha a mesma concepção nem o mesmo entendimento das sutilezas de um jogo erótico visual, composto de imagens perversamente ambivalentes, próprias do século XX. Supor, como o faz Edward Lucie-Smith ${ }^{18}$ (1995), que as representações dos corpos condenados no Inferno do Juízo Final de Giotto na Capela Scrovegni em Pádua, representam uma atração sádica pela violência e tortura de natureza sexual, por parte do artista, é simplificar demasiadamente o erótico medieval e associá-lo erroneamente a um sentido de perversão sexual contemporâneo, bem diferente do existente na época da Idade Média. Fora o fato de que a imagem do nu medieval, e mesmo a dos corpos pendurados no Inferno de Giotto, tinham

\footnotetext{
${ }^{13}$ LE GOFF Jacques; SCHMITT, Jean-Claude. Dicionário Temático do Ocidente Medieval, Bauru, Editora da Universidade do Sagrado Coração, 2002, Tomo I. P. 328.

14 Idem.

15 LINK, Luther. O Diabo, A Máscara sem Rosto, São Paulo, Editora Schwarcz, 1998, p. 156.

${ }^{16} \mathrm{O}$ sadismo foi um termo criado por Richard von Krafft-Ebing em 1886, tirado do Marques de Sade, para designar uma perversão sexual - pancadas, flagelações, humilhações físicas e morais - baseada num modo de satisfação ligado ao sofrimento infligido ao outro.

${ }^{17}$ Sobre o assunto do imaginário erótico e da sexualidade medieval recomendo a leitura do capítulo Sexualidade, constante no Dicionário Temático do Ocidente Medieval, Tomo II, pp. 477-493, de Jacques Le Goff \& JeanClaude Schmitt, Editora da Universidade do Sagrado Coração, São Paulo, 2002.

18 LUCIE-SMITH, Edward. Sexuality in Western Art, London, Thames and Hudson, 1995, p. 34.
} 
por pressuposto uma linguagem visual em que preponderavam os atributos simbólicos, não possuindo o caráter mais naturalista, mundano e sensual das representações posteriores, a partir do nu renascentista.

Mas, nem tanto ao mar, nem tanto a terra. $\mathrm{O}$ nu medieval tinha lá sua atração. Não se pode ignorar o conteúdo erótico que o nu sempre possuiu, dependendo do contexto em que se coloca, é claro. Kenneth Clark (1956) bem comenta a esse respeito:

No imaginário popular da Idade Média, uma mulher nua tem exatamente o mesmo significado que conserva no imaginário popular de sempre. E a degradação que o corpo sofreu, como resultado da moralidade cristã, serviu para aumentar o seu impacto erótico. $^{19}$

Em outras palavras, a forma do corpo nu por si, sempre foi capaz de suscitar os desejos sexuais, de realizar a correspondência visual do stimuli fisiológico. Por isso concordo apenas em parte quando Luther Link (1998), no seu livro O Diabo, A Máscara sem Rosto, diz que "a partir do início da Idade Média, homens e mulheres nuas no Inferno foram sexualmente desinteressantes porque as técnicas medievais antigas não conseguiam evocar um corpo humano sólido, carnudo (nem tencionavam isso)”. É óbvio que, de uma certa maneira, para o olhar contemporâneo, uma comparação direta dessas imagens produzidas em tempos e contextos diferentes, privilegiaria de imediato o aspecto erótico dos imaginários naturalistas do Renascimento em diante, em detrimento das simbólicas medievais. Mas não se deve daí inferir que o imaginário do nu medieval, por si, não possuísse nenhum apelo sensual, e seria absurdo pensar que a Idade Média fosse destituída de representações eróticas. A "carne concupiscente, fonte de impulsos dificilmente refreáveis", ${ }^{20}$ era consideravelmente presente na vida de então, e motivou inclusive toda uma vasta categoria do imaginário erótico, podendo-se dizer que "consideradas em conjunto, as realidades medievais dos reinos da carne foram menos uniformes, menos austeras e menos repressivas do que os historiadores do passado compraziam-se em crer". 21

\footnotetext{
${ }^{19}$ CLARK, Kenneth. op., cit, p.253.

20 SCHMITT, Jean-Claude \& Jacques Le Goff, op., cit, Tomo II, p. 338.

21 Idem, p.492.
} 


\section{ANATOMIAS DO CORPO}

De qualquer modo, o Inferno de conteúdo sensual e erótico mais evidente só pôde surgir a partir do Renascimento italiano, quando o imaginário do nu voltou-se, progressivamente, a uma noção do belo, semelhante a da Antiguidade greco-romana. E quando o estudo anatômico do corpo, expressão do entusiasmo científico do Renascimento, se tornou um meio representativo da conjugação do conhecimento com a experiência visual ${ }^{22}$.

Para que o imaginário do corpo nu fosse natural e convincente criou-se, durante o Renascimento, a necessidade de um conhecimento mais profundo da sua estrutura formal. Isso significou ter que se estudar a sua constituição anatômica. Implicou também, numa atitude diferente dos artistas, que a partir daí vislumbraram novas possibilidades expressivas nas representações do corpo humano. Em consonância com a avidez pelo conhecimento científico, eles fizeram pleno uso da geometria e da perspectiva. A ânsia de sintetizar arte e ciência levou o homem renascentista a explorar o corpo humano não só em termos estéticos, nos muitos tratados de proporções e medidas editados então ${ }^{23}$, como também em termos científicos, voltados para o estudo da anatomia, em que a ilustração científica, de mais qualidade, inaugurou-se nos trabalhos de investigação anatômica de Leonardo da Vinci $^{24}$ e Andreas Vesalius ${ }^{25}$. O próprio Signorelli, dizem, fazia incursões aos

22 É a fórmula proposta por Kenneth Clark no seu livro $O \mathrm{Nu}$.

23 Cito como exemplo inicial a obra intitulada De Pictura do arquiteto, pintor, filósofo e crítico de arte, Leon Battista Alberti (1404-Gênova, 1472-Roma), que foi o primeiro texto na literatura artística a constituir a pintura como objeto de teoria e doutrina sistematizadas. Consta uma passagem, bastante elucidativa na questão da representação do corpo, da vestimenta e da anatomia, no parágrafo 36, do livro segundo, que diz:

"Mas como, para vestir uma pessoa, primeiro a desenhamos nua e depois a envolvemos de pano, da mesma forma, ao pintar um nu, primeiro colocamos os ossos e os músculos, que depois cobrimos com as carnes, de tal modo que não é difícil perceber onde se encontra cada músculo".

A contribuição seguinte foi do pintor alemão Albrecht Dürer (1471-1528), com o seu tratado intitulado $O s$ Quatro Livros sobre a Proporção Humana, que foi publicado postumamente. A publicação espelhou o envolvimento de Dürer com os aspectos teóricos da perspectiva e com as proporções humanas. Menciono, por fim, a obra de Leonardo da Vinci, que dada a sua dispersão geográfica nunca pode ser publicada na sua inteireza, mas que, mesmo fragmentada e mutilada nos seus manuscritos, representou uma importante fonte de referências concernentes à anatomia e proporção da figura humana.

24 Leonardo foi o único artista da época a considerar o estudo da anatomia humana como uma disciplina à parte, e não apenas como um estudo auxiliar na arte de representar o corpo. Sugiro, no tocante aos seus manuscritos anatômicos, a leitura do livro Leonardo on the Human Body, publicado pela Dover Publications, New York, 1983.

${ }^{25}$ Andreas Vesalius (1514-1564), foi um famoso médico anatomista flamengo que publicou o seu trabalho mais conhecido, De Humani Corporis Fabrica em 1543. Este trabalho teve suas ilustrações provavelmente elaboradas por artistas vinculados ao atelier de Ticiano, uns dizem que pelo próprio, outros que por Kalkar, ou Campagnola e até por Vesalius, visto que a controvérsia da autoria das pranchas é bastante acentuada entre os estudiosos da matéria. De qualquer maneira, a qualidade das pranchas anatômicas não tinha paralelo na época. 
cemitérios em busca de partes de cadáveres para estudar anatomia. De acordo com Vasari, Antonio Pollaiuolo dissecava muitos corpos para examiná-los interiormente, tendo sido o primeiro artista a mostrar um método de exploração dos músculos, para fins de arte.

A relação entre arte e anatomia encontra um curioso paralelo entre o trecho bíblico que fala sobre a ressurreição dos mortos, e a estética do nu na pintura recomendada por Leon Batista Alberti. A visão dos ossos secos de Ezequiel, constante na Bíblia ${ }^{26}$, diz: "E porei sobre vós nervos, e farei crescer carnes sobre vós, e sobre vós estenderei pele: e dar-vos-ei o espírito, e vós vivereis e sabereis que eu sou o Senhor". No seu livro De Pictura, Leon Batista Alberti indica como necessária uma conformação do corpo na pintura segundo as etapas consecutivas do desenho, em primeiro lugar, de ossos e de músculos para, em seguida, cobri-los de pele e carne.

Os estudos anatômicos que se fizeram a partir do Renascimento, e que mais tarde integraram os currículos das academias de arte, possibilitaram o surgimento de um aspecto novo e crucial na relação entre arte e anatomia, que foi adentrar os mistérios do interior do corpo humano. Principiou-se uma divisão do corpo que passou a articular um espaço externo, o do corpo estético, na maioria das vezes idealizado, da arte, tradicional e concebido no território das convenções históricas, e um interno, até então quase nada explorado, do organismo humano, da medicina, o corpo tabu, região proibida de ser manipulada por interdições que remontam à Antigüidade grega. A divisão do corpo em dentro e fora induziu ao fascínio do fragmento corporal, da parte que substituiu o todo no conjunto das imagens repartidas e dos corpos em pedaços, que influenciaram o imaginário da arte do ocidente, paulatinamente, do século XVI em diante. A paisagem interna do corpo, em termos da representação de imagens, está ligada ao amor, ao gozo e à vida, no seu aspecto prazeroso, e ao ódio, ao sofrimento e à morte, no seu lado terrível. Essas categorias de sentimentos, de sensações e de estados emocionais opostos, são alternados na existência corporal, tanto concreta como imaginária. Mesmo antes da aventura da arte moderna, num tempo em que a pele se apresentava como uma barreira quase insuperável aos olhos dos artistas, certas imagens impressionantes eram encontradas nas representações de torturas e de pesquisa científica, a partir do Renascimento. Pinturas e esculturas do mito grego de Apolo escorchando o fauno Marsias, que o deus derrotou numa disputa musical, e dos martírios cristãos de São Bartolomeu e de São Vicente, eram iconografias

${ }^{26}$ Ezequiel (37,6), Bíblia Sagrada, Edição Barsa, 1965. 
representativas do corpo aberto e fragmentado. Essas representações contrastavam com o corpo canônico inteiro e idealizado da herança clássica. A arte que primeiro nos introduziu ao labirinto dos nossos corpos assim o fez com a devida inocência, própria do período histórico em que prevaleciam as questões religiosas da fé cristã.

A culminação desse longo processo cíclico e histórico de dissolução e reconstrução do corpo aconteceu no período do pós-guerra de 1945, quando certas vertentes da arte se afastaram da representação do corpo, e de um ponto de vista perceptivo, para o domínio da abstração e da arte conceitual.

Entretanto, o atual interesse pelas questões do corpo em muitas manifestações na arte, com renovadas preocupações de identidade, de gênero, de política e de sexualidade, parece representar um novo foco, diferenciado, nas relações das imagens do corpo com as sociedades. Só que no prisma do século XXI, os "artistas não mais se referem ao desenho da 'figura', mas sim ao 'corpo', que é concebido como uma construção cultural carregada de significados de natureza social, sexual, e de gênero". ${ }^{27}$

Mas acontece que, ao mesmo tempo em que o corpo se tornou um objeto de estudo aprofundado e começou a ser subordinado as regras anatômicas, e em que as primeiras academias foram fundadas em Florença no século XVI, o imaginário do Inferno sofrem uma espécie de desregramento funcional e teológico. Isto porque o Inferno foi transfigurado por algumas grandes obras do Renascimento, em que os corpos demoníacos e supliciados foram enobrecidos pela beleza, e, a partir do momento em que o espectador os admirou, deixou de haver o medo.

\section{O CORPO NO JUÍZO FINAL}

Exemplares dessas novas representações dos corpos nus estão, por exemplo, nos infernos dos Juízos Finais de Luca Signorelli e Michelangelo, onde o conhecimento da anatomia é preponderante e acaba por suplantar o significado teológico ao qual as figuras pintadas deveriam subordinar-se. Não é mais aquele Inferno "verdadeiro" feito nos moldes das temíveis visões medievais, e sim "uma criação pessoal, original, saída do espírito do artista e sempre diferente". ${ }^{28}$

\footnotetext{
27 PETHERBRIDGE, Deanna. The Quick and the Dead, University of California Press, 1997, p. 10.

28 MINOIS, George. História dos Infernos, Lisboa, Editorial Teorema, 1991, p.248.
} 
O tema do Juízo Final teve uma longa e complexa evolução artística datando do século XII ao século XVI, na Itália. As suas origens iconográficas encontram-se nos mosaicos da igreja de Torcello, perto de Veneza, no século XII. Tiveram um desenvolvimento original feito por Giotto na capela Scrovegni em Pádua, bem como pelo ciclo executado por Orcagna na igreja de Santa Maria Novella em Florença, em torno do final do século XIV. A última significativa utilização da temática do Juízo Final foi no afresco executado por Michelangelo na parede atrás do altar da capela Sistina em Roma no século XVI.

A complexidade histórica da iconografia do Juízo Final envolveu e articulou um vasto conjunto de imaginários temáticos secundários e dependentes, como por exemplo, a morte, o Inferno e o Diabo, sempre a serviço da didática religiosa da Igreja.

De acordo com o exposto por Luther $\operatorname{Link}^{29}$ na sua análise das implicações temáticas dos juízos finais e dos apocalipses na arte, o princípio do Juízo Final não é o do conflito, mas sim o da harmonia por intermédio de um julgamento e de uma separação. É como se fosse uma máquina de julgar: ocorrem ajustes, mas não há uma luta real. A balança da pesagem das almas faz a separação dos eleitos e dos condenados. Maria e João intercedem aqui e acolá. Mas quando soa a última trombeta e os mortos retornam à vida o ajuste final é feito para todo o sempre. O efeito disto é o medo. No seu aspecto pedagógico a temática do Juízo Final foi direcionada contra os inimigos externos da Igreja e que, portanto, constituiu o tema dos tímpanos de muitas catedrais góticas. Em complementação, teve-se o tema do Apocalipse, que se ocupava da heresia interna da Igreja durante a codificação da doutrina cristã entre os séculos VIII e XI.

O Inferno do Juízo Final de Orvieto, feito por Signorelli, comporta, em termos iconográficos gerais, o programa simbólico religioso preconizado pela Igreja, mas no tocante a representação dos corpos dos demônios e dos danados, indica uma nova direção, que irá influenciar inclusive, o afresco do Juízo Final pintado por Michelangelo, na Capela Sistina. Signorelli, inebriado pelo estudo da anatomia, pinta corpos em que "uma ênfase vigorosa é dada aos músculos e tendões, de tal modo que alguns dos seus diabos estão como que écorchés". ${ }^{30}$ Suas figuras personificam "uma energia demoníaca, triunfante também a seu modo, que irá reaparecer no movimento romântico do princípio do século XIX, nos condutores de escravos e carrascos de Géricault, e em certos 'espíritos diabólicos

29 LINK, Luther. op., cit, pp.118-129.

30 CLARK, Kenneth, op., cit, p. 171. 
de Blake". ${ }^{31}$ Luca Signorelli, um dos grandes mestres da escola úmbrica, foi contratado para decorar a Capela da Nossa Senhora de S. Brizio, na Catedral de Orvieto em 1498.O trabalho incluiu sete grandes temas: Sermões e Feitos do Anticristo; Fim do Mundo; Ressurreição da Carne; Os Danados; Os Eleitos; O Paraíso; e o Inferno. A tarefa deu continuidade aos afrescos iniciados por Fra Angelico, em 1447 e interrompidos em 1449, nas abóbadas da capela e se estendeu para as paredes laterais onde Signorelli pintou os temas citados. Tecnicamente falando, Signorelli atingiu um estilo de grandiosidade épica, que mais tarde causou profunda impressão em Michelangelo, mediante a combinação de influências em que constavam mestres como Piero della Francesca (pela solidez cúbica da forma e domínio do escorço) e Pollaiuolo (pela energia, expressividade e precisão anatômica dos seus nus).

Em termos da convenção de representar a hierarquia religiosa nos juízos finais, Signorelli seguiu a tradição histórica fazendo constar no seu afresco as figuras do Cristo Juiz, da Virgem Maria, dos apóstolos e dos Santos, como também os instrumentos da paixão e da crucificação. Neste ponto, a única exceção é a ausência do arcanjo Miguel que tem as suas costumeiras atribuições sendo cumpridas por grupos de anjos músicos e guerreiros.

Os afrescos comprovaram o fascínio de Signorelli pela postura teatral e corporal, mais do que teológica, dos personagens da sua narrativa visual. Neste particular, a sua representação do Inferno se tornou emblemática e estabeleceu uma nova ênfase na figuração do corpo. A atenção dispensada no tratamento anatômico das figuras humanas indicou uma nova tendência clássica da representação idealizada do corpo, e um elemento iconográfico de relevo e importância na história da arte do Renascimento italiano. Esta insistência na temática do corpo aponta um outro nível de mudança histórica, que é o da substituição do símbolo medieval pelo humanismo impregnante da Renascença.

O Inferno de Signorelli, segundo a interpretação de Luther Link, apresenta uma massa densa de corpos nus amontoados, de demônios humanizados a supliciar belas mulheres danadas, que na sua maior parte eram sexualmente atraentes, e homens danados atléticos, todos na sua melhor aparência corporal e juventude. Conforme Link observa, "crueldade e dor não são excepcionais em Juízos Finais, mas Signorelli parece ter sido o primeiro a usar

31 Idem, p. 171. 
as torturas como moldura para fantasias sexuais sádicas de estupro por diabos". ${ }^{2}$ As atitudes das mulheres pintadas, cativas e desamparadas, em sua maioria passivas, para com os demônios de meia-idade, musculosos e vigorosos, que as torturam, são acentuadamente ambíguas. Pelo menos para um olhar contemporâneo, como o de Link. Mas para um observador instruído da época, esta interpretação talvez pudesse ser considerada excessiva, ou até mesmo equivocada, ao levar-se em conta que as escrituras e as autoridades teológicas afirmavam que as terríveis punições impostas aos pecadores no Inferno, não deveriam induzir sentimentos de piedade nos virtuosos. Tomás de Aquino, na Suma Teológica, chegou mesmo a escrever uma recomendação para que os eleitos se regozijassem na contemplação dos sofrimentos impostos aos danados do Inferno.

Entretanto, há numa imagem de especial destaque, um detalhe curioso, que indica, a meu ver, uma mudança e tanto nas relações entre demônios e danados: no alto, bem no centro do grupo dos condenados, existe um demônio voador com uma expressão bastante maliciosa na face. Ele está a carregar nas costas uma bela mulher loura, de madeixas onduladas e esvoaçadas, de expressão apreensiva, que o abraça de maneira insegura. Ela olha para o lado, para um anjo guardião do céu, como se quisesse lhe suplicar ou pedir algo. As mãos do demônio seguram as mãos da mulher, ou melhor, as envolvem. A mão esquerda do demônio, especialmente, com a palma por sobre a parte superior da mão também esquerda da mulher, entrelaça, carinhosamente, os seus dedos com os dedos dela. E ela, por sua vez, dobra os dedos numa hesitante aceitação da insinuação erótica demoníaca. Cria-se uma relação de certa intimidade, de natureza sensual, entre estes dois personagens do teatro erótico do além. Personagens que se encaixariam perfeitamente num quadro como $O$ Embarque para Cítera, a ilha dos sonhos e dos amores, do êxtase sublime e dos sentimentos de paixão, que o pintor francês Antoine Watteau, o especialista das fêtes galantes e cenas românticas do século XVIII, terminou em 1718.

${ }^{32}$ LINK, Luther. op., cit, p. 164. 


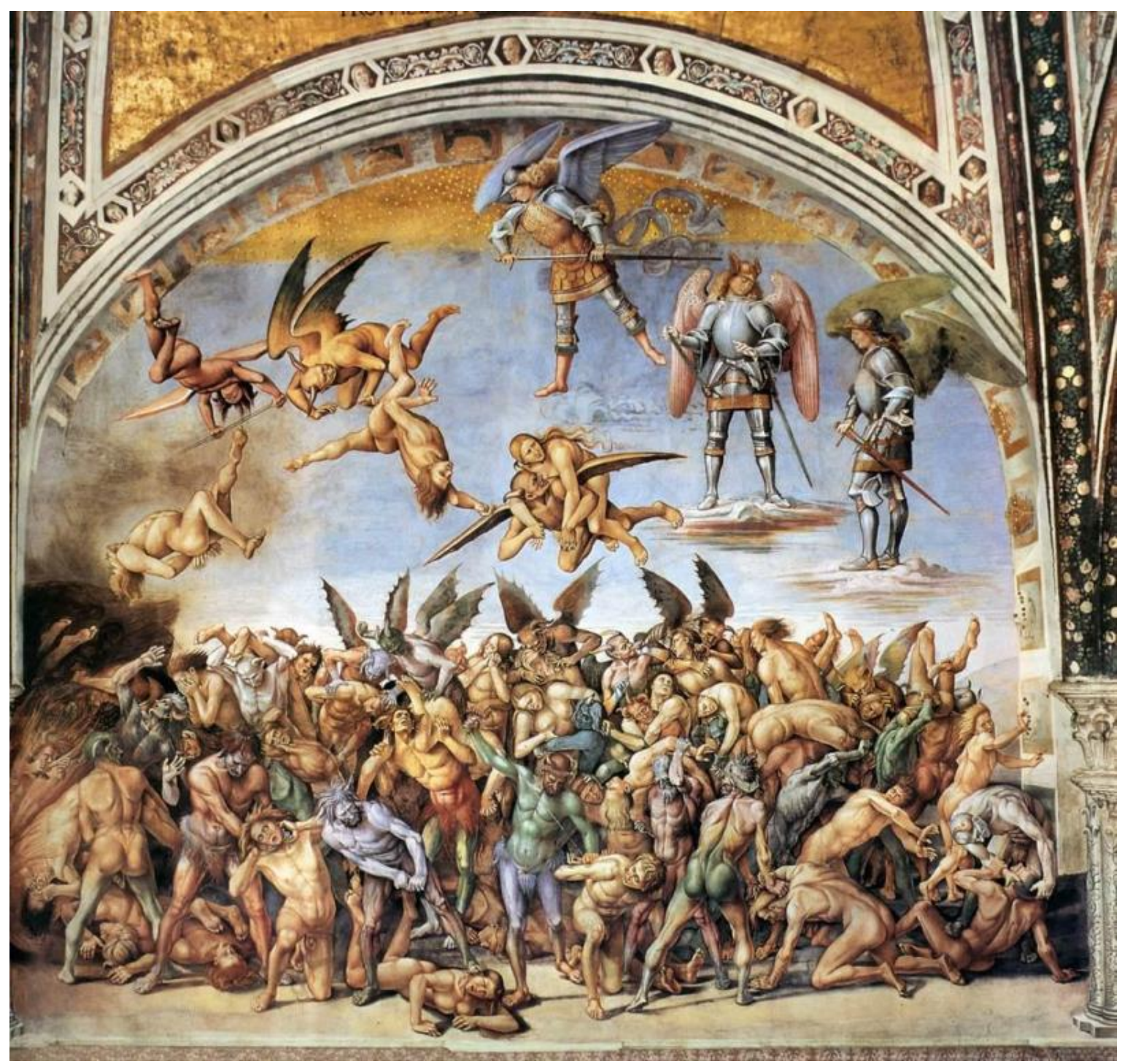

Signorelli, Luca. Juízo Final

Imagens de demônios carregando danados às costas eram comuns na época, e Signorelli devia estar bastante familiarizado com elas. Exemplo interessante, a iluminura do início do século XV, feita pelos Mestres de Dirc van Delf, iluminadores da região flamenga, mostra uma Boca do Inferno do livro A Mesa da Fé Cristã. A ilustração exibe uma flamejante boca do inferno de perfil na sua base, com um Satã preto dentro, a recolher almas danadas, que lhes são entregues por dois demônios. $O$ da esquerda leva uma alma sentada nos seus ombros, muito contrita e pequena, numa atitude muito parecida com a de um pai que leva o filho às costas. Um outro exemplo, que talvez ajude a entender melhor a ambigüidade da imagem de Signorelli, pertence ao gênero da sátira. Trata-se de uma xilogravura inglesa do século XIV, que mostra demônios jocosos a carregar nas costas, segurando pelos 
tornozelos, jovens cervejeiras de cabeça para baixo, para as jogar na boca do inferno ${ }^{33}$ (MORGAN, 1996). Seu pecado foi ter vendido cerveja adulterada e de péssima qualidade. Essa representação provavelmente se baseou no teatro popular, pois conforme explica Alice Turner "algumas vezes a encenação da Descida de Cristo ao Inferno tinha um pequeno addendum, a história da Cervejeira, posta ao Inferno por aguar a cerveja, e que fica atrás para se casar com um dos demônios”34 (TURNER, 1995). Muitas dessas peças datam já do século XII e eram representadas por toda a Europa, da Tchecoslováquia a Inglaterra, e em muitos lugares eram compostas em ciclos que apresentavam a "história do mundo" da Criação ao Juízo Final. Cervejeiras eram mulheres que atendiam nas cervejarias medievais, espécies de garçonetes, que algumas vezes eram as proprietárias desses estabelecimentos. A relação de certa intimidade que percebi na representação do demônio e da mulher de Signorelli, talvez aluda à história da cervejeira.

A razão iconográfica e religiosa que levou Signorelli a imaginar e pintar tal cena, pode residir na interpretação que Jonathan B. Riess ${ }^{35}$ dela fez, relacionando a investida sensual do demônio com a predisposição e a suscetibilidade feminina ao apelo sexual, em termos da norma religiosa vigente na época:

\begin{abstract}
A capacidade de ameaça sexual, que os demônios predadores possuem, vêm à tona assim que o malicioso demônio volta-se na direção da sua presa indefesa, seu corpo flácido e pesado fundindo-se ao dele, ao tempo em que ele a puxa firmemente para baixo pelos seus braços. Aqui está descrito, em essência, a fabulosa potência e o fascínio dos poderes infernais, há muito tidos como uma das armadilhas pelas quais as mulheres são levadas ao seu terrível destino (Por essa razão acreditava-se serem as mulheres particularmente vulneráveis aos truques amorosos de Satã). (RIESS, 1995)
\end{abstract}

Admito o argumento de Riess em parte, principalmente no tocante a suscetibilidade histórica e feminina ao diabólico, visto que o cristianismo sempre impôs um rígido sistema normativo na conduta sexual, especialmente a das mulheres. Mas no tocante ao imaginário da figura humana, Riess incorre num engano, a meu ver, de interpretação da imagem do corpo nu da mulher, ao lhe atribuir os adjetivos flácido e pesado. O que Signorelli

\footnotetext{
33 MORGAN, Genevieve. The Devil, San Francisco, Chronicle Books, 1996, p. 74.

34 TURNER, Alice. The History of Hell, New York, Harvest Book, 1995, p. 120.

35 RIESS, Jonathan B. Luca Signorelli, The San Brizio Chapel, New York, George Braziller, 1995, p. 68.
} 
pretendeu e fez, pelo menos com relação ao sentido de beleza da sua época, foi retratar, o melhor que pôde, o corpo de uma bela mulher. Riess classificou, equivocadamente, e com um olhar demasiadamente comprometido com a contemporaneidade, alguns aspectos convencionais dessa imaginário, como desvios do padrão de beleza feminina renascentista. Como pintor, e também como professor de anatomia artística, costumo tratar as questões da elaboração das imagens do corpo humano com a relatividade inerente da prática do atelier e, portanto, acredito ser oportuno aqui, fazer um comentário mais detalhado a esse respeito. Lanço mão de uma situação hipotética paralela para melhor expor as razões que, a meu ver, levaram Signorelli a pintar a mulher danada dessa maneira. E para contrapor a avaliação estética que Riess dela fez.

Ao representar, de uma maneira razoavelmente realista, uma mulher nua numa pintura, o artista vai precisar de uma considerável experiência e de um conhecimento substancial da forma do corpo humano, para levar a sua tarefa a um bom termo. Será necessária alguma familiaridade com as proporções e medidas do corpo e uma certa noção dos aspectos da sua anatomia. Sem estes conhecimentos básicos a representação terá uma grande chance de se tornar inviável ou tender para uma imagem de aparência primitiva, desproporcionada e ignorante. $\mathrm{O}$ uso do modelo vivo será recomendável para a melhor representação dos detalhes e das minúcias do corpo. Mas para o artista experiente, isso poderá se tornar dispensável, dependendo do grau exigido de fidelidade à realidade. Se for mediano, ele poderá utilizar-se da sua memória para realizar a pintura, pois ela abriga o conhecimento acumulado de experiências anteriores. Se a exigência for alta, ele terá de usar o modelo e o seu conhecimento ao mesmo tempo, fazendo uma mediação entre o que ele vê e o que ele sabe, na relação dinâmica, de tentativa e erro, entre a sua percepção e a sua memória. Com o tempo e a prática, ele desenvolve um esquema mental que o auxilia na imitação da realidade, classificando, ordenando e discriminando, como num jogo de vai-e-vem, entre as formas reais percebidas e as mentais, onde a experimentação continuamente modifica a memória. Mas a memória do artista, tanto se refere à realidade anteriormente experimentada, quanto ao seu aprendizado de figuras realizadas por outros artistas, em outras pinturas. Se a mulher nua a ser representada for uma figuração relacionada ao Além, como por exemplo, uma alma danada do Inferno, o artista será obrigado a recorrer ao estoque de figuras fantásticas daquela memória coletiva, denominada de imaginário, que é compartilhada com toda a sociedade na qual ele vive. A partir daí, serão múltiplos estratos da memória ecoando na consciência do artista; a memória do corpo específico do modelo, 
a memória dos corpos apreendidos de representações de modelos feitas por outros artistas, a memória das figurações do imaginário, e assim por diante, num processo que tende a maior complexidade formal e simbólica, na medida em que são acumuladas novas exigências na execução da imagem, e dependendo, claro, da capacidade, talento e conhecimento do artista.

Busquei expor de forma resumida, nesse último parágrafo, a lógica da fabricação de um tipo específico de imagem da pintura (a mulher nua como danada no inferno), baseado na minha experiência como pintor e à luz do estudo de Gombrich ${ }^{36}$ da psicologia da representação pictórica. Em Arte e Ilusão, Gombrich (1986) estuda a história e a psicologia da representação pictórica, levando em conta as atuais teorias da percepção visual. Ele reexamina muitas ideias a respeito da imitação da natureza e da função da tradição na elaboração das imagens. Na sua investigação da mimese, Gombrich sustenta que sem um meio expressivo e sem um esquema capaz de ser moldado e modificado nenhum artista pode imitar a realidade. Ele denomina este esquema, na verdade um modelo relacional, de schematta, e aí centra o seu argumento de negação da teoria do olhar inocente. "Não é o registro fiel de uma experiência visual, mas a construção fiel de um modelo relacional”37 o que o artista faz ao copiar a natureza, diz Gombrich. O processo perceptivo, segundo ele, não é passivo e gera uma expectativa, de natureza conceitual, anterior mesmo ao objeto a ser copiado. Daí dizer-se que "a percepção pode ser vista como, essencialmente, a modificação de uma antecipação". ${ }^{38}$ Ao tornar relativa a noção mais comum que temos da imitação da natureza, Gombrich enfatiza o processo técnico, o estilo e o fazer na arte, chegando mesmo a inverter a usual formulação da mimese quando diz que "a pintura é uma atividade, e o artista tende, conseqüentemente, a ver o que pinta ao invés de pintar o que vê". ${ }^{39} \mathrm{O}$ estudo de Gombrich, ao concentrar-se nos aspectos fenomenológicos do processo perceptivo e da representação das imagens, não esquece a importante vinculação social do artista na fabricação das imagens, ao analisar questões atinentes ao problema do

\footnotetext{
${ }^{36}$ GOMBRICH, Ernst H. Arte e Ilusão. Um estudo da psicologia da representação pictórica, São Paulo, Martins Fontes, 1986.

37 Idem, p. 79.

38 Ibidem, p.151.

39 Ibidem, p. 74.
} 
estilo quando diz que "a forma de uma representação não pode estar divorciada da sua finalidade e das exigências da sociedade na qual a linguagem visual dada tem curso". 40

Por conseguinte, na representação da mulher danada, Signorelli utilizou claramente de uma schematta, no sentido Gombrichiano do termo, tornando evidente o apego às visualidades anatômicas e a exploração de diferentes atitudes e gesticulações corporais, tão valorizadas na arte do Renascimento. No caso mais específico dos corpos femininos, a geometrização básica da sua construção indica nitidamente o modo pelo qual foram elaborados. Numa comparação das representações femininas do Inferno com as do Paraíso, e mesmo com as da Ressurreição dos Mortos, pintadas na parede oposta e na lateral, respectivamente, podese facilmente constatar que foram realizadas segundo a mesma schematta. A utilização de formas ovais e esféricas nos desenhos dos corpos é dominante, sendo que as simplificações de blocos cúbicos e cilíndricos eram aplicadas às perspectivas das figuras, para facilitar a representação do escorço ${ }^{41}$, especialmente nos demônios que voam e nos danados que caem no Inferno. O corpo nu feminino típico de Signorelli segue um padrão estético vigente na Itália do século $\mathrm{XV}^{42}$, em que o volume do corpo todo era consideravelmente maior do que na magreza característica das regiões do norte europeu. Entretanto, compartilhava com o norte, a mesma estética da herança gótica, presente na acentuada distância da linha da cintura, elevada e pouco marcada, com a pélvis, rebaixada, resultando num torso alongado e num ventre proeminente. Quanto aos seios, apesar de exageradamente esféricos ${ }^{43}$, são delicados e menores, seguindo a tendência da maioria dos nus do renascimento. As faces apresentam uma solução que se aproxima da formulação clássica simplificada, enfatizando o geral em detrimento do particular, não retratando nenhuma personalidade específica ${ }^{44}$.

${ }^{40}$ Ibidem. p. 79.

${ }^{41}$ Na prática, o escorço é uma aplicação específica da perspectiva, significando a ilusão de diminuição criada num objeto longo e visto a partir de uma das suas extremidades. Constituiu uma dificuldade privilegiada pelos amatore delle difficulta, segundo consta nas paginas 214-217, do O Olhar Renascente: Pintura e Experiência Social na Itália da Renascença, de Michael Baxandall. Leitura, aliás, bastante recomendável para se aprofundar nesse aspecto específico da pintura renascentista.

${ }^{42}$ O padrão a que me refiro consta na caracterização do nu feminino renascentista proposta por Anne Hollander no seu estudo da relação do corpo nu e vestido, em Seeing Through Clothes na página 100.

43 Esfericidade função de uma schematta ainda não suficientemente desenvolvida para a representação de uma forma mais realista, em que os elementos particulares fossem mais detalhadamente representados, como nos nus dos séculos posteriores, principalmente a partir do século XVII.

44 Aqui me refiro tão somente às faces das representações das mulheres no painel do inferno, não sendo a observação extensiva aos outros episódios pintados na capela. No painel do Reinado do Anticristo, por exemplo, Signorelli representa a si próprio junto ao retrato de Fra Angélico, ao qual presta uma homenagem. 
Logo, no meu entendimento, a mulher carregada pelo demônio voador era um protótipo de mulher bela, embora estivesse destinada à danação, um exemplo característico e formador da categoria dos corpos punidos no Inferno do Renascimento.

Some-se a isso o fato de que não havia razões iconográficas para que os corpos dos danados fossem representados grotescamente ${ }^{45}$, mesmo no Inferno, visto que no episódio da ressurreição, conforme o próprio Reiss informa:

Esqueletos metamorfoseam em corpos na ilustração, segundo Signorelli, do processo evolucionário pelo qual as almas invisíveis e ensombrecidas, assumem mais uma vez, a corporeidade no dia do Juízo Final. Todas as anormalidades físicas desaparecem. A humanidade, despertada e renovada, torna-se perfeita na sua completude. Todos são belos e na mesma idade (trinta, precisamente, a idade na qual Cristo triunfou sobre a morte na sua ressurreição), de acordo com o programa extraordinariamente detalhado para a ressurreição da humanidade, que emergiu no final da Idade Média após séculos de intensos debates. ${ }^{46}$ (RIESS, 1995)

45 Das representações que tive a oportunidade de estudar, somente uma mostrou a categoria de corpos danados grotescos presentes no inferno. Trata-se da pintura intitulada A Queda dos Danados, de 1620, de autoria do pintor Peter Paul Rubens, que se encontra atualmente, na Alte Pinakotek de Munique, na Alemanha. Mesmo assim, os corpos grotescos parecem referir-se mais a um dos pecados capitais, a gula, sendo representada por dois danados homens e uma mulher, todos obesos e sendo arrastados para a profundeza do inferno por furiosos demônios mordedores.

46 RIESS, Jonathan B. Luca Signorelli, The San Brizio Chapel, Orvieto, George Braziller, Inc., New York, 1995 , p.54. A descrição se refere ao painel da Ressurreição dos Mortos, que antecede o momento do Juízo Final e da distribuição das almas para o Paraíso ou o Inferno. Mas existe uma outra interpretação do episodio feita por Tomás de Aquino, na Suma Teológica, que diferencia os corpos dos danados dos corpos dos eleitos. Diz o santo que na ressurreição, sim, os corpos dos condenados serão "físicamente" diferentes dos corpos dos eleitos: "Eles ressuscitarão na idade perfeita, sem qualquer diminuição dos membros, sem nenhum dos defeitos ou enfermidades que um erro da natureza ou uma doença pode introduzir na Terra. (...) Mas porque a sua alma se afastou voluntariamente de Deus e foi destituída do seu próprio fim,os corpos não são espiritualizados, isto é, não serão inteiramente submetidos ao espírito, enquanto a alma, pela sua afetividade, será carnal. Tal como os corpos dos condenados, não terão essa agilidade que sem dificuldade os tornaria obedientes em relação a alma: pelo contrário, serão incômodos e pesados e de certa maneira insuportáveis para a alma, porque a própria alma, pela sua desobediência, se afastou de Deus. (...)Por fim, esses corpos serão opacos e tenebrosos, tal como as suas almas que se vêem privadas da luz do divino conhecimento". A citação encontra-se na p. 223, do livro de Georges Minois intitulado de História do Inferno. Existe também mais uma outra referência à questão da ressurreição, que segundo Clark era o modelo que os artistas do século XII usualmente seguiam para representar a cena. Eram instruções que estavam "contidas no Speculum de Vincent de Beauvais, onde se dá ao assunto uma interpretação diretamente derivada da filosofia humanista da Grécia. Estabelece-se que na $<<$ Ressurreição $>>$ as figuras levantando-se do tumulo não só devem estar despidas mas que cada uma deve apresentar-se num estado de perfeita beleza segundo as leis da existência”. Kenneth Clark, $O N u$, Editora Ulissea, Lisboa, p. 248. 


\subsection{O JUÍZO FINAL DE MICHELANGELO}

Michelangelo recebeu a incumbência de executar o afresco do Juízo Final em Roma no ano de 1533, feita pelo Papa Clemente VIII. Os movimentos da Contra-Reforma possivelmente levaram o sumo pontífice a optar por esta temática. Deveria ser um manifesto Anti-Reforma. Da encomenda inicial constava mais um afresco na parede oposta com o tema da Ressurreição que acabou não sendo realizado. O levantamento dos andaimes do afresco teve início entre abril e agosto de 1535 e a monumental obra terminada foi exposta ao público em outubro de 1541.

Do ponto de vista formal, trata-se de uma obra gigantesca, contando com 411 figuras humanas representadas no tamanho médio variando de 2,0 m a 2,5 m cada uma. Embora nos estudos iniciais Michelangelo tenha procurado respeitar os limites projetados segundo os afrescos existentes nas paredes da capela, especialmente o de Perugino (Natividade e Moisés encontrado nos Arbustos), mais tarde ele mudou a concepção da obra. Segundo estudos posteriores, decidiu ocupar toda a superfície da parede atrás do altar. Michelangelo já havia pintado todo o teto com o tema da Gênese 29 anos antes. Formalmente, as distâncias entre os dois afrescos são numerosas. Ao enquadramento repetido do teto, por exemplo, corresponde a sua ausência total no juízo. Como bem o coloca Sergio Ferro : (...) "a pintura elimina a arquitetura, fura a parede, abre a igreja (...) Atrás do altar, o Juízo elide o suporte que o permite" ${ }^{\text {47 }}$ (FERRO, 1981).

Michelangelo substituiu o conceito teológico medieval da Providência e introduziu a noção mais antiga do fatum, a idéia de um destino inexorável que deixa os mortais à mercê do medo e da incerteza. De fato, isto implica numa outra característica do afresco que é a ausência do tema corrente da pesagem das almas, feita pelo arcanjo Miguel, na grande tradição dos juízos finais. A divisão e o encaminhamento das almas ao Paraíso ou ao Inferno, que em outros juízos finais é organizada segundo esta convenção, passa a ser confusa e feita por meio de lutas encarniçadas entre almas, anjos celestes e demônios, no afresco de Michelangelo. As virtudes ou pecados das almas parecem já não pesar em nada, pois que a divisão depende da determinação dos anjos e demônios que, por elas, lutam entre si. Em contraste com Signorelli, que representou um esquema cósmico e ordenado e que incluiu a promessa da eterna salvação no Paraíso do seu Juízo, Michelangelo eliminou

\footnotetext{
${ }^{47}$ FERRO, Sergio. Michelangelo, São Paulo, Palavra e Imagem, 1981, P.75.
} 
toda a hierarquia e projetou, tanto os eleitos como os danados, no mesmo espaço plano, juntos no mesmo e único movimento, que num momento ascende às alturas celestes (no caso não muito promissoras) e no outro desce às profundezas infernais (certamente punitivas).

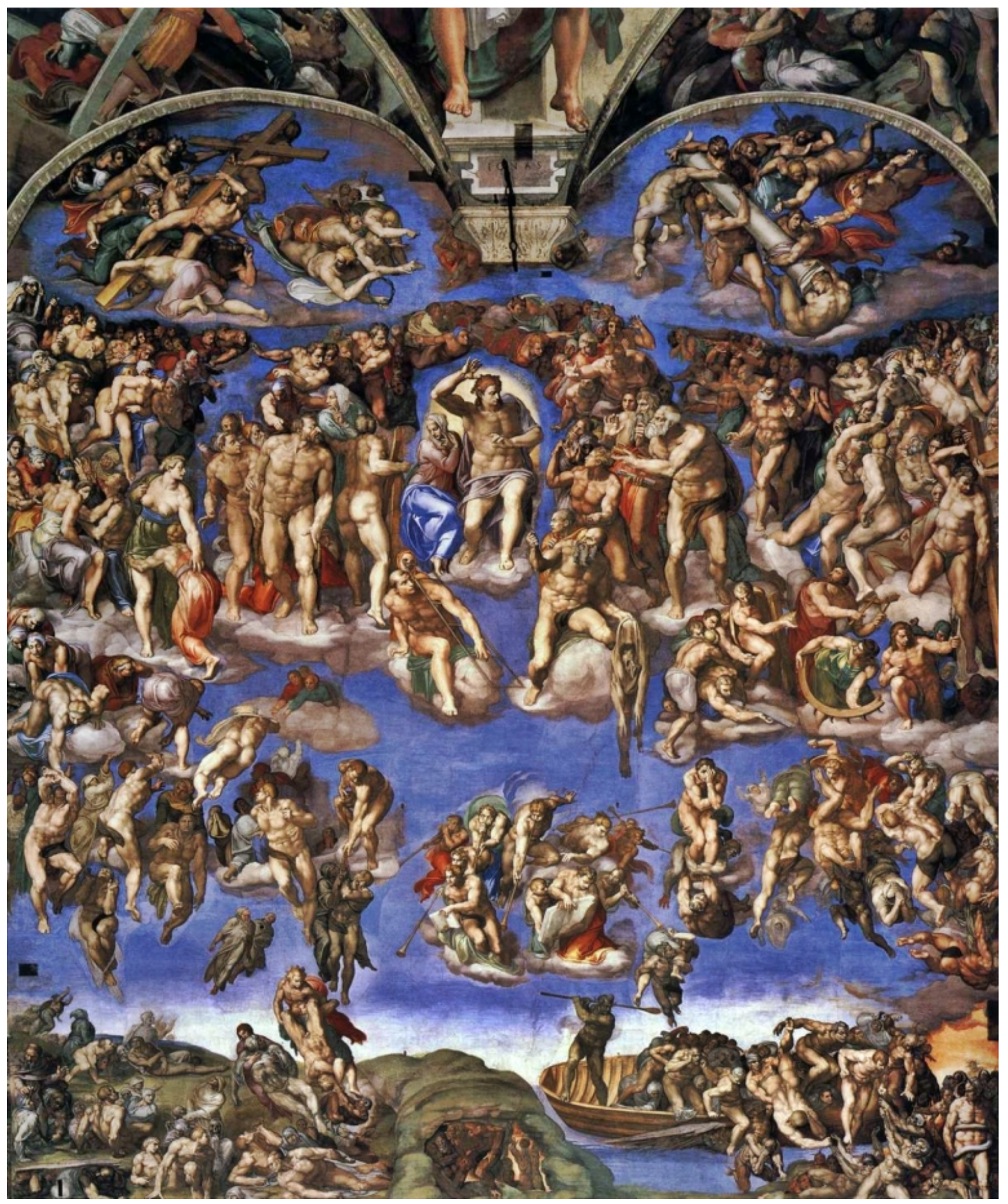

Michelangelo, Juízo Final 
No tocante ao aspecto iconográfico do Juízo Final, Michelangelo utilizou as principais temáticas da tradição cristã, como o lugar central ocupado por Cristo, o Juiz e a Virgem Maria, bem como a descrição dos instrumentos da paixão e da crucificação nos dois espaços superiores opostos. As modificações iconográficas que Michelangelo introduziu na imagem do Cristo, Maria e na multidão de santos e dos apóstolos, já constam de diversos e importantes estudos. A área que aqui mais interessa diz respeito à representação do Inferno. Nele, Michelangelo utilizou o repertório da iconografia de Dante, de forma modificada, nas figuras dos grupos dos danados, dominados pelas presenças de Caronte, o barqueiro do Inferno e Minos, o juiz das almas pecadoras. A modificação que mencionei é no tocante à aparência física, tanto de Caronte, quanto de Minos, que de acordo com Barnes (1998) “(...) não se ajustam à descrição de Dante; apenas os seus gestos sim,48.

O barqueiro do Inferno, na interpretação de Michelangelo, apesar de manter sua identidade como uma figura mitológica, na sua corpulenta figura, de trajar um panejamento esvoaçante ${ }^{49}$ (o que figura como uma capa as suas costas) e de não ostentar o par de chifres típico dos demônios medievais, mais se aparenta com um deles, devido ao fato de apresentar longas orelhas pontudas, garras e uma face de características felinas. $\mathrm{Na}$ descrição de Dante, Caronte é um velho, branco de antigo pêlo e enrugado, de olhos em brasa e vestido em trapos. De acordo com a limpeza feita recentemente no afresco, o corpo de Caronte é verde, o que na simbologia medieval, ainda vigente na ocasião, significava um dos pecados mortais, o da inveja. $\mathrm{O}$ fato de ele estar batendo nas almas danadas com o remo pode implicar num elo cênico, segundo Barnes (1998), entre o episódio do embarque das almas, onde isso realmente acontece (no Inferno, Canto III, versos 109-11) e o julgamento de Minos, que só se dá no Canto V, versos 4-21, após terem passado pelo limbo dos poetas e filósofos. A direção do seu olhar para a outra margem onde se encontra o terrível Minos, indica a ligação entre as duas cenas.

Minos, por sua vez, se apresenta no afresco na versão de uma criatura corpulenta de orelhas de asno, com uma serpente (que morde o seu pênis) em sua volta e não uma cauda

48 BARNES, Bernardine. Michelangelo's Last Judgement: The Renaissance Response, Berkeley,University of California Press, 1998, p. 114.

49 O tapa sexo foi uma intervenção posterior à morte de Michelangelo, inicialmente feita pelo artista Daniele da Volterra (vulgo "Braghettone"), que foi contratado pelo Concilio de Trento com a finalidade de "moralizar o Juízo". As intervenções restantes se estenderam até o século XIX. 
enrolada, como em Dante. Barnes sugere uma possível representação de Satã na sua figura numa transferência simbólica interessante, imaginativa e bem fundamentada. A ausência da representação explícita do rei do Inferno e mesmo a falta de ênfase no espaço dedicado à representação do próprio Inferno, poderia ser função da execução de um outro painel na parede de entrada da capela. Este painel teria como tema a massiva queda dos anjos rebeldes, que apesar de pouco comum na data (Miguel combatendo Satã era uma iconografia mais comum, então), estaria com sua execução prevista segundo os primeiros esboços feitos pelo artista. Como o painel não foi realizado, a representação do Juízo Final terminou por incorporar o episódio da queda. Assim, o Inferno sofreu uma drástica redução no seu espaço de representação e o Demônio teve de se acomodar na sua transferência iconográfica para a figura do juiz infernal Minos.

Mas o conhecimento de Michelangelo, da Divina Comédia, era bem além do nível popular e simplista, e muitos membros da sua audiência na Capela Sistina, tinham o tempo e, presumivelmente o conhecimento, para apreciar as referências mais sutis" ${ }^{\circ 0}$ (BARNES, 1998).

È interessante notar que em termos de influências iconográficas a relação se mostra recíproca entre Dante e os pintores. A figura do seu Satã de três cabeças provávelmente foi inspirada por concepções de pintores. Dante, como grande parte de Florença, deve ter visto o espetacular mosaico do novo Juízo Final da cúpula do batistério da catedral de São Giovanni, terminado em 1300, dois anos antes dele ser banido (não esqueçer que a Divina Comédia foi escrita no seu exílio).Acrescente-se o fato de que, segundo nos conta Vasari no seu livro Vidas dos Artistas (1550), Dante era "um querido amigo" do pintor Giotto, que também era florentino. Depois de seu exílio ele evidentemente visitou a capela Scrovegni em Pádua, onde Giotto terminou os seus famosos afrescos em torno de 1307. Ambos os juízos finais exibem Satãs bestiais com um par de serpentes devoradoras de danados no lugar das orelhas. Como em termos descritivos, as serpentes teriam parecido mais exóticas do que poéticas, Dante reorganizou a imagem de tal forma a estabelecer um paralelo com a Santíssima Trindade.

A síntese do Hades cristão, feita por Dante, resulta particularmente significativa na compreensão da iconografia presente nos juízos finais de Michelangelo e Signorelli, ambos

\footnotetext{
${ }^{50}$ BARNES, Bernardine. op., cit, p.107.
} 
seus notórios leitores. Mas não se deve exagerar o feito, visto que a influência de Dante nas imagens do Inferno se fez sentir só a partir do final do século XIV, e mesmo assim muitos artistas eram relutantes ou incapazes de transformar as suas sugestões literárias em imagens pictóricas. Existia o problema de representar numa pintura de duas dimensões a complexa topografia tridimensional do seu inferno, de formato cônico. Além do que a representação dos suplícios constantes em Dante requeria um conhecimento da literatura clássica. Daí é que o esquema anterior dos sete pecados capitais continuou sendo a fonte principal das representações do Inferno que os artistas, na sua maioria, utilizavam. Era uma questão de tornar mais compreensível uma imagem para aqueles que tinham somente um vago conhecimento da cultura clássica.

Apesar da obra de Dante versar sobre uma aventura moral e redentora do espírito no Além, é na sua constante menção ao corpo físico, como a principal figuração do Inferno, que o relato adquire força e convencimento dramático. A corporificação da alma pecadora na carne ressurrecta, passível de punição, é o fundamento essencial do castigo exemplar do Demônio, e a razão de ser do Inferno no cerne da crença cristã. $O$ vigor imaginativo de Dante no Inferno centra-se na plasticidade das formas - ele pensava por via das imagens simbólicas. As metáforas corporais, recurso literário abundantemente utilizado por Dante, indicam o itinerário de uma verdadeira geografia corporal no Inferno. Os diversificados exemplos dos corpos gigantescos aí presentes designam a geografia do corpo infernal, transformado no corpo mundo - Satã, o protagonista peludo do Inferno, cujo imenso corpo se confunde com o buraco maldito; Anteu, o gigante africano devorador de leões, e que junto aos seus companheiros Efialte, Briareu e Nemrod, provocam terremotos terríveis ao movimentar-se; e Gerião, o monstro alado e transportador de Dante e Virgilio.

Quanto aos corpos dos danados, eles são regidos pela lei de Talião, cada um tendo o castigo correspondente ao seu pecado. Dante distribuiu os pecados no esquema das transgressões de crescente gravidade, com base na doutrina aristotélica, em quatro categorias principais: incontinência, violência e bestialidade, fraude simples e traição. $\mathrm{O}$ corpo supliciado conforma a principal iconografia do Inferno, e os castigos corporais, muitos deles aplicados por diligentes categorias de demônios menores, são dos mais variados tipos: imersão na lama fétida, no sangue fervente do rio Flegetonte, no piche quente, flechadas, dilaceramentos, esquartejamentos, queimaduras pelo fogo ardente, picaduras de serpentes e de vespas. 
O corpo danado no Inferno jesuíta, por sua vez, enfrenta uma nova situação. Cessam todas as torturas exceto o fogo, e todos os monstros, exceto o verme que nunca dorme. Em compensação, entra um novo suplício, que busca definir um sistema normativo de punições eficiente, e condizente com as necessidades do imaginário do século XVI. Num ambiente claustrofóbico, úmido e repulsivo, se apertam, de corpos colados, de ventre com traseiro, de boca com boca, aristocratas e prósperos comerciantes, com mendigos imundos e fedidos, com vermes e feridas pustulentas, com leprosos e com habitantes dos bairros miseráveis e sujos. É um Inferno feito sob medida para despertar o temor da classe média e da aristocracia. Os corpos dos danados neste Inferno ficariam inchados, flácidos, infectados, repugnantes, esmagados juntos como uvas numa prensa de vinho. Não há latrinas. O fedor infernal é de gente, e é repulsivo e eterno, é composto de sujeira, de fezes, de pestilência, de feridas abertas com pus, de mau hálito, e de tudo o mais que os jesuítas julgassem apropriado para causar temor e arrependimento nos seus ricos clientes. É o Inferno da promiscuidade absoluta e do compartilhamento da imundície. Mas no terreno da arte, era inconveniente traduzir esta literalidade do esgoto e da sujeira para imagens religiosas. A representação do Inferno barroco teve então de encontrar alternativas em imagens que enfatizassem, sobretudo o caráter teatral, espetacular e dramático, da sua mentalidade religiosa.

\subsection{O JUÍZO FINAL DE RUBENS}

O estúdio de Pieter Paul Rubens (1577-1640), um dos mais famosos e prolíficos pintores holandeses do século XVII, recebeu, em 1615, a encomenda do Conde WolfgangWilhelm, para executar um Juízo Final para a Igreja jesuíta de Neuburg. Conhecido como o Grande Juízo Final, a obra foi completada entre os anos de 1615-1616. A obra, realizada em grande parte pelos seus assistentes, é uma interpretação barroca do Juízo Final de Michelangelo. A ira divina em Rubens é concebida como uma composição oval da carne, um crescendo de salvação e danação do corpo. O corpo danado no Inferno, que é o que aqui mais interessa, mereceu uma atenção especial por parte do estúdio de Rubens, tanto que foi executada uma segunda obra, ligada ao tema do Juízo Final e intitulada de Queda dos Danados. Essa obra encontra-se atualmente na Alte Pinakothek de Munique. No centro da pintura, um pouco abaixo, Rubens pintou um interessante grupo de danados obesos. 
Contradizendo o programa da ressurreição da Igreja ${ }^{51}$, que prevê corpos perfeitos, ou interpretando expressamente o episódio em que, segundo Tomás de Aquino, os corpos condenados "serão incômodos e pesados e de certa maneira insuportáveis para a alma, porque a própria alma, pela sua desobediência, se afastou de Deus" ${ }^{, 52}$, Rubens representou três danados, dois homens e uma mulher a serem carregados pelos demônios ${ }^{53}$. Seus corpos são claramente obesos e um deles é atacado às mordidas, no flanco e no braço, por dois demônios. Aqui, Rubens faz pleno uso da categoria de demônios mordedores, introduzida por Michelangelo no seu Inferno do Júzo Final ${ }^{54}$. A representação desses corpos gordos, pesados e excessivos, pode ainda estar vinculada ao pecado da gula, um dos sete pecados capitais, e nesse caso, os demônios mordedores estariam, na verdade, a devorar o danado, nessa canibalização tão característica dos demônios medievais. E representativa também, de uma inversão punitiva demoníaca daqueles excessos gastronômicos cometidos em vida pelos pobres danados.

$\mathrm{Na}$ pintura de Rubens o suplício dominante aplicado aos corpos danados é o da devoração, exercida por vários tipos de figurações demoníacas e bestiais. Existem ainda puxões de cabelos, chaves de braço e esganações de todas as espécies. Os puxões de cabelos são quase que exclusivamente aplicados às mulheres, podendo com isso, significar a punição do pecado da luxúria. Servem também, como um diferente recurso formal de enfatizar a curva descendente, que vai do Céu às profundezas do Inferno. Demônios enfileirados seguram nos cabelos das danadas, formando uma extensa cadeia de corpos infernais que se precipitam nas regiões abissais. O corpo danado de Rubens é a expressão própria e dinâmica, em toda a significação do termo, da culpa e do desespero interior das almas condenadas ao suplício eterno. Os corpos danados são mostrados nas mais variadas e intensas contorções possíveis, dobrados, torcidos, esticados, enroscados e flexionados, levando aos limites extremos a terribilitá típica do corpo michelangesco. E, do ponto de vista da composição, esses corpos se dispõe numa estrutura de curvas e volutas, de ovais e elipses, de enroscamentos, onde tudo flui, ininterruptamente, onde as linhas conduzem o olhar numa trajetória serpenteante, que termina na profunda escuridão do Inferno. A curva

\footnotetext{
51 RIESS, Jonathan B. op., cit, p. 54.

52 MINOIS, Georges. História do Inferno, Lisboa, Teorema, 1997, p. 223.

53 Existe um estudo específico desse grupo de danados obesos, feito por Rubens e bastante interessante, e que pode ser consultado na página 178, do livro Figure Drawing, de autoria de Nathan Goldstein, Prentice Hall, New Jersey, 1993. o desenho original encontra-se no Museu Britânico, em Londres.

54 No Inferno do Juízo Final de Michelangelo, logo abaixo da barca de Caronte, está representado um demônio voador a carregar um danado, que ele morde, violentamente, numa das pernas.
} 
do corpo danado, o seu enroscamento, semelhante ao da serpente, simboliza em Rubens, os ciclos do vício e da degradação moral da humanidade pecadora.

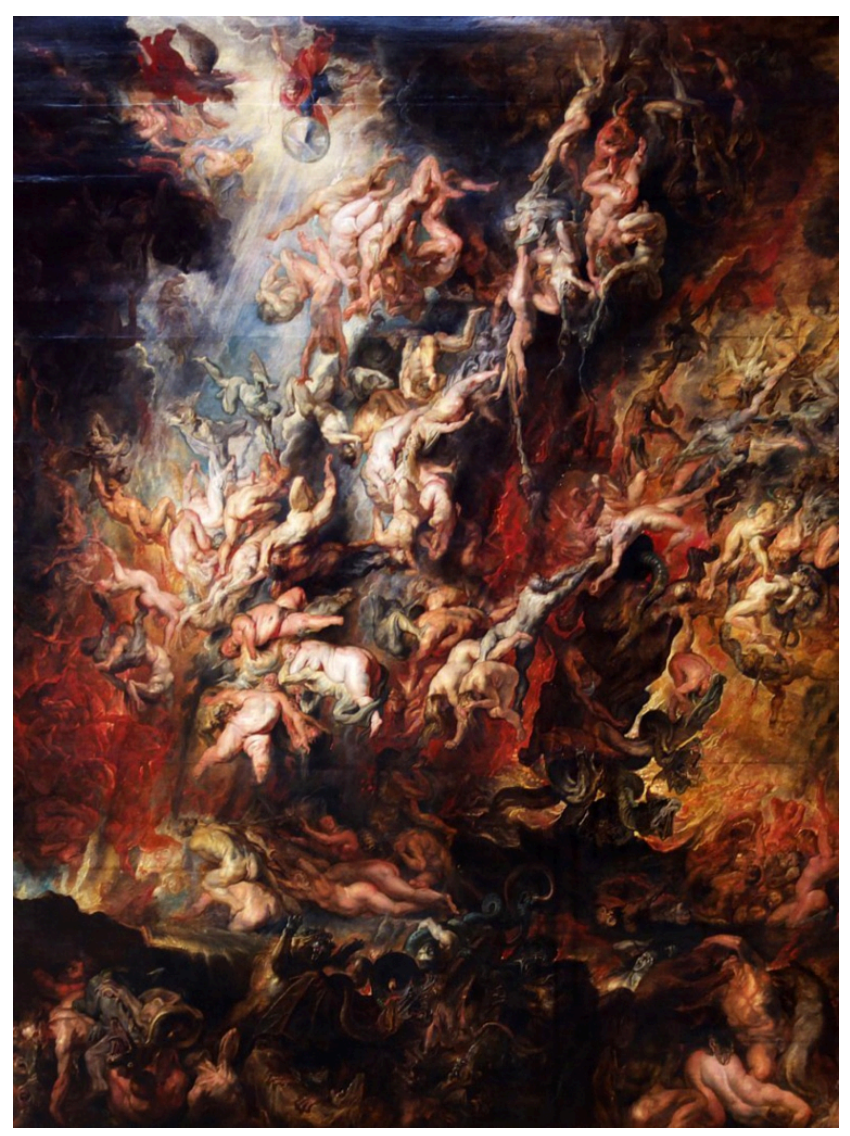

Rubens, Pieter Paul, Queda dos Danados

Na composição da pintura Rubens organiza uma verdadeira sinfonia da carne danada, se ocupando mais da expressividade da enorme massa composta de corpos que se precipitam no Inferno do que num cumprimento estrito de ordem iconográfica deste episódio bíblico. A vertigem da queda fica acentuada pela progressiva materialização que os corpos danados vão adquirindo na medida em que se precipitam nas profundezas do abismo. A escala usada nas cores contribui em muito para esse paulatino ganho de peso visual dos corpos. No topo à esquerda, dominam os fulgores e a claridade amarelada divina, impondo-se sobre o fundo azul do céu e onde figuram os anjos guerreiros a expulsar os danados. Nessa altura, os corpos danados são ofuscados pela fúria da luz divina, predominando os ocres e carnações esmaecidas. No centro da pintura, os tons ficam mais contrastados, sombras profundas acentuam as carnações de matizes mais realçadas, 
entram os vermelhos das chamas, os contornos são mais definidos, e na base, predominam as sombras e os tons escuros da profundeza infernal.

Com relação aos corpos demoníacos representados na pintura, Rubens baseou as iconografias na tradição, especialmente nos demônios do Juízo Final de Michelangelo, mantendo as características gerais dos demônios humanóides do renascimento. A essas representações ele acrescentou um grupo de figuras bestiais e monstruosas, parecidas com lobos, ursos e leões. No seu bestiário, Rubens também faz figurar a mitológica hidra, monstro de várias cabeças de dragão, a devorar danados. Estão representadas também, algumas variações iconográficas que fundem o corpo do demônio humanóide com o da serpente, o mesmo híbrido constante em algumas pinturas flamengas do século $\mathrm{XV}$, mais especificamente na Queda do Homem de Hugo Van Der Goes ${ }^{55}$, atualmente no Kunsthistorisches Museum de Viena, bem como na representação italiana do Demônio, na Tentação do Éden, no teto da Capela Sistina, feito por Michelangelo. Na pintura de Rubens, a exemplo da tradição flamenga, inexiste a representação de Satã, cuja iconografia estará, até o princípio do século XVII, mais vinculada às questões da magia negra e feitiçaria. De acordo com o programa de banimento de Satã e dos demais demônios do Inferno, implementado pelos jesuítas, a legião infernal estará destinada mais às transações com bruxas, feiticeiros e a magia negra.

Rubens faz da expressão do corpo humano um símbolo tão profundo do Inferno que prescinde da existência de instrumentos de tortura, tão comuns na Idade Média.

\section{ANIMA DANNATA}

Anima Dannata é o título de um estudo fisionômico feito pelo escultor italiano Gianlorenzo Bernini. Este busto, esculpido em mármore em 1619, durante o seu período romano de formação, é um auto-retrato, um estudo particularizado da sua expressão facial. A peça foi concebida para fazer par a uma outra imagem, de uma jovem que levanta a vista para o céu, e que foi intitulada de Alma Bendita. A busca da verdade no instantâneo, a investigação das reações emocionais, e em especial as expressões de surpresa, temor ou perturbação, são características do caravaggismo ${ }^{56}$ de Bernini. E fazem parte da estratégia

\footnotetext{
55 O lagarto com cabeça humana de Hugo, aliás, é um dos precursores da humanização da serpente, como símbolo do Demônio medieval.

56 Michelangelo Caravaggio, pintor italiano, nascido em 1571 e falecido em 1610, um dos representantes notáveis do barroco na Italia, destacou-se principalmente pelo intenso "realismo" das figuras e cenas bíblicas que
} 
temática e formal da arte religiosa do barroco, orientada pelos jesuítas, que visa ao engajamento das emoções dos fiéis. O ponto mais importante aqui é o processo segundo o qual os imaginários do Paraíso e do Inferno, com toda a sua variedade de iconografias, irão se resumir a esses dois bustos antagonistas, a duas expressões faciais de êxtase místico e de horrível desespero, respectivamente. Antagonismo que, por sinal, é sinônimo do recurso estilístico por excelência da arte barroca: o contraste.

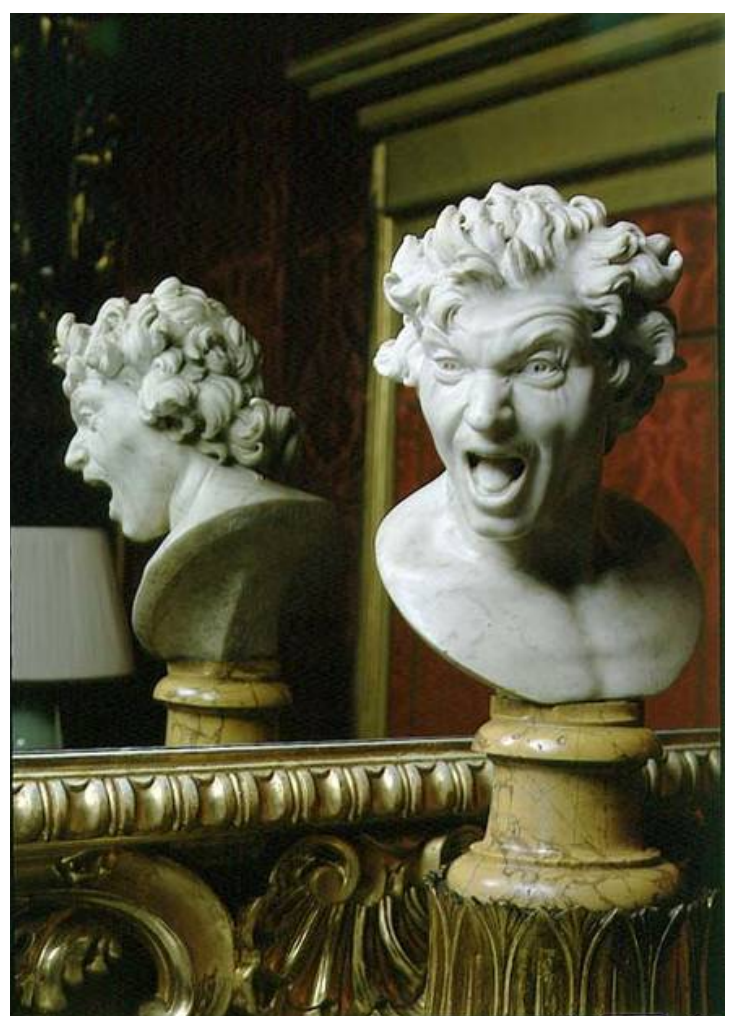

Bernini, Giamlorenzo, Anima Dannata

No tocante ao Inferno, a Alma Danada sintetiza o desespero cristão interiorizado, eleva a emoção ao máximo de expressividade, não se esquecendo de que Bernini, segundo Émile Male, “(...) comungava duas vezes por semana, além de submeter-se, todos os anos, aos

representava. De acordo com Howard Hibbard, em seu livro Caravaggio, Thames \& Hudson, Londres, 1993, p. 190: "Caravaggio pintava pessoas reais, que pareciam se projetar para dentro do nosso próprio espaço e vida, pelo contraste da escuridão atrás delas. $\mathrm{O}$ artista que melhor soube compreender o que Caravaggio fez nas Capelas de Cesari e Cavalieri, foi Bernini, que traduziu o imediatismo das pinturas de Caravaggio para a estatuária, e em ultima instância, para a experiência visual e emocional emoldurada por uma capela ou até mesmo por uma igreja. Mas ele substituiu a representação mundana das pessoas feita por Caravaggio pelas suas figuras idealizadas em mármore". 
Exercícios Espirituais de Santo Inácio de Loyola"(...) ${ }^{57}$. Esta sentimentalização da imagem infernal é que vai influenciar as contorções corporais agônicas, torturadas e teatrais da Porta do Inferno de Rodin ${ }^{58}$. O corpo humano demoníaco e sofredor, passa a simbolizar todo o espaço do Inferno. Já não se fazem mais necessárias iconografias da tradição, como a paisagem de rochas, as chamas, os demônios e nem os objetos de suplícios. Desfaz-se de qualquer menção ao ambiente infernal e mesmo ao corpo inteiro; tudo agora se resume numa fisionomia de horror. É o retrato do homem se infernizando, e a terrível paisagem do Inferno, espiritualmente absorvida e mentalmente vivenciada, se desenha nas suas rugas crispadas, nas sobrancelhas arqueadas, nas narinas dilatadas e nos olhos protuberantes, na boca escancarada a gritar de horror, e nos cabelos desordenados, próprios da inquieta geometria barroca. O significado metafórico dessa expressão do inferno espiritual e interiorizado no individuo, não era, naturalmente, destinado a ser compreendido pela população simples e iletrada. De acordo com Minois (1997), "existem realmente dois infernos no Grande Século: o da gentalha e o dos debochados aristocráticos. Enquanto os primeiros se debatem na imunda cloaca, amontoados, estilhaçados, queimados e gelados, os segundos meditam sobre o remorso" ${ }^{\text {59 }}$. Mas como nem as representações violentas e vulgares do Inferno popular, e nem a perturbação e o remorso do Inferno aristocrático pareciam assustar muito os cortesãos dos séculos XVII e XVIII, restou à arte da ContraReforma buscar na exacerbação do conteúdo emocional das suas imagens, o elemento de inquietação espiritual interior, de ordem passional, que doutrinasse o público mais esclarecido. Mas isso ao preço de abandonar o princípio simbólico que havia organizado suas representações religiosas por séculos de história. "A Igreja já não se contenta em expor os dogmas de sua Fé, como ocorria nos séculos passados; agora ela se propõe a defendê-los, a demonstrá-los"60. Não foi outro o objetivo do complexo de imagens barrocas do que suscitar emoções e sentimentos nos fiéis que as contemplavam.

57 TREVISAN, Armindo. O Rosto de Cristo: A Formação do Imaginário e da Arte Cristã, Porto Alegre, Editora Age, 2003, p. 246.

58 Embora a ênfase da Porta do Inferno de Rodin seja no corpo, existem obras expressivas, que a ela se relacionam e que se concentram na fisionomia agônica das personagens retratadas. É o caso da Cabeça da Dor, de 1882, fragmento que pertencia a um dos filhos de Ugolino, grupo integrante da Porta do Inferno, e que, posteriormente, ganhou autonomia. Outro exemplo é a Mulher que Chora ou A Carpideira, um bronze de 1893, que chegou a integrar a base da Porta, sendo mais tarde retirada e apresentada individualmente. Por fim, consta um desenho intitulado de Cabeça de Homem Inquieto, de 1896, que é muito semelhante à estátua da cabeça danada de Bernini.

${ }^{59}$ MINOIS, George. op., cit, P. 289.

${ }^{60}$ TREVISAN, Armindo. op., cit, p. 246. 
A Alma Bendita e a Alma Danada, ambas representadas por Bernini, seriam os dois lados do corpo cristão, dois estados de ânimo incessantemente antagônicos, constituintes da alternância do impulso superior da fé que aponta para o alto, e do instinto carnal inferior que arrasta para o abismo.

Em vista disso, Minois (1997) indica a atualidade da concepção sentimental barroca na consciência do homem do século XX:

O Paraíso e o Inferno não seriam então mais do que duas facetas contraditórias de uma mesma realidade no homem? Duas virtualidades da pessoa que se realizam de forma alternada? Satã não é um anjo? O homem não é ao mesmo tempo condenado e eleito, bom e mau? Este caminho parece ser o único que está aberto à reflexão neste fim do século XX. No seu Paraíso Perdido, Milton escrevia:

O espírito é o seu próprio lugar e nele podem fazer-se

Dos infernos os céus, e dos céus um inferno ${ }^{61}$ (MINOIS, 1997).

O fogo é a essência do Inferno. Nele se incorpora e se faz figurar, desde o início e através dos séculos, em quase todas as versões européias do mundo inferior. A noção mesma de um fogo sem luz, o fogo negro do Inferno, que aumenta as trevas em vez de as dissipar, que na concepção de Santo Agostinho é o fogo que queima a alma sem consumila, e na de São Marcos aparece comparado ao sal - omnis enim igne salietur, o fogo estará neles como o sal ${ }^{62}$ - é que vai constituir o princípio geral da punição do corpo pecador. A didática do medo encontra nos sermões cristãos dos séculos XVII e XVIII todos os tipos de absurdos e exageros, de alucinações sádicas e oportunistas, e o fogo do Inferno era uma oportunidade para as mais variadas comparações, como esta, constante na Coleção Integral e Universal das Orações Sagradas:

Os condenados apenas conhecerão o fogo, respirarão o fogo, terão em todo o lado um espaço prodigioso. O fogo será o elemento que sempre os há de alimentar e conservar para sempre os atormentar. Insinuar-se-á até a medula dos ossos, atingirá todas as partes do seu corpo e penetrá-las-á inteiramente. A sua língua será como uma barra de ferro em brasa, os lábios como placas de cobre a arder, o palato da boca como uma

61 MINOIS, Georges. História dos Infernos, Lisboa, Teorema, 1997, p. 433.

62 Idem, p. 275. 
fornalha em brasa, os dentes como pedaços de aço ao rubro, os pulmões como foles de fogo, o estômago e o ventre como um cadinho em que se depuram os metais mais $\operatorname{duros}^{63}$ (MINOIS, 1997).

Observar-se no trecho citado uma interessante metáfora corporal alusiva ao corpo fogo no Inferno, um corpo que se faz barra de ferro, fole e fornalha, e no qual todos os instrumentos característicos do trabalho de uma ferraria se apresentam, ordenadamente, na purgação dos pecados que corrompem este mesmo corpo. De acordo com Santo Hilário "esse fogo queima a carne e impede-a ao mesmo tempo de se corromper"

Sobre o fogo do Inferno diz ainda Santo Agostinho, em Civitate Dei, preocupado em incluir a categoria dos corpos demoníacos nos suplícios juntamente com a dos danados, que ele será um fogo corpóreo e atormentará os corpos, sejam de homens ou de demônios, que a ele estarão unidos para receber a pena, não para vivificá-lo. Termina por falar desse fogo que será único para ambos, como o próprio Deus assegurou.

No seu aspecto negativo e destruidor, o fogo é de fato uma função diabólica, mas tem também na forja um duplo significado: seu fogo é, ao mesmo tempo, celeste e subterrâneo, instrumento de demiurgo ${ }^{65}$ e de demônio. A natureza do calor, proveniente do fogo é ambígua. Quando intenso, desmesurado, transcendente, ele pode queimar agressivamente as coisas. Traduz-se pela fúria divina, a Deus irae, o fogo do Juízo final. Que nos diga o padre jesuíta La Colombière, capelão da duquesa de York em Londres, num sermão feito nos anos 1670-1680, inteiramente representativo do que se escutava na época:

O fogo do inferno é o efeito de uma força irritada, da raiva infinita do Criador: é um instrumento de cólera e de vingança, apenas foi criado para atormentar; e como todas as qualidades que Deus lhe concedeu para esse fim se revelassem ainda muito fracas, como se toda a sua onipotência nada pudesse fazer para corresponder à sua cólera, assim junta-se a esse fogo, regula a sua atividade e aplica-o pelas suas próprias mãos, acrescenta ao seu natural ardor tudo o que em si existe de força e de discernimento para se tornar mais violento e mais cruel.

63 Ibidem, p. 277.

64 Idem, p. 283.

65 Refiro-me aqui ao deus do fogo grego Hefestos, que na versão romana é chamado de Vulcano, o ferreiro do Olimpo. 
Um Deus cruel, sem sombra de dúvida, a despeito dos mais nobres e divinos desígnios. Mas que tem a sua contrapartida benigna. Pois o fogo, quando tépido, controlado, imanente, aquece, acalenta, cria as condições para a vida, não só do homem como também de todos os outros seres na terra.

Esta universalidade ígnea cuja propriedade de fazer corresponder temperaturas opostas ao aquecer a matéria, articula uma vasta categoria de significações do fogo. Na mitologia grega, por exemplo, representou um símbolo de civilização, tendo sido dado aos homens por Prometeu. Na sua versão benigna o fogo é o elemento da vida, que anima, é íntimo e universal, reside no coração e ascende ao céu. "Sobe das profundezas da substância e se oferece como um amor" ${ }^{\text {"66 }}$, diz poeticamente Bachelard (1999), na sua imaginação do fogo. Diz ainda que no pólo oposto o fogo "torna a descer à matéria e se oculta, latente, contido como o ódio e a vingança" ${ }^{67}$. Dentre todos os fenômenos, é realmente o único capaz de receber tão nitidamente as duas valorizações contrárias: o bem e o mal. Ele brilha no Paraíso, abrasa no Inferno. È doçura e tortura"68. Como diz Bachelard (1999), "o fogo é, dentre os fatores de imagens, o mais dialetizado. Só ele é sujeito e objeto. Quando se vai ao fundo de um animismo, encontra-se sempre um calorismo".

De acordo com Junito Brandão (1997), “a grande queda de nível é a de Lúcifer, ‘o que leva a luz celeste', precipitado nas fornalhas do inferno: um fogo que brilha sem consumir, mas exclui para sempre toda e qualquer possibilidade de regeneração".

Numa metáfora alusiva ao trauma sofrido após a queda no interior do mundo, pode-se falar da "regressão"69 do Demônio, da sua "necessidade de penetrar, de ir ao interior das coisas" ${ }^{70}$, do recolhimento fetal, movido por "uma sedução da intuição do calor íntimo", ao interior quente do orbe, nas profundezas obscuras da terra, a ela se ligando, numa espécie de retorno ao morno útero materno: a terra mater. Ao estreitamento desta cálida

\footnotetext{
66 BACHELARD,Gaston. A Psicanálise do Fogo, São Paulo, Martins Fontes, 1999, p. 11.

67 Idem, p. 11.

${ }^{68}$ Ibidem., p.11.

69 De acordo com Junito Brandão, as grutas e cavernas desempenhavam um papel religioso muito importante em todas as culturas primitivas. A descida a uma caverna, gruta ou labirinto simboliza a morte ritual, do tipo iniciático, onde o indivíduo experimenta uma ida aos começos do mundo e às origens do ser. Diz ele: "Esta catábase é a materialização do regressus ad uterum, isto é, do retorno ao útero materno, donde se emerge de tal maneira transformado, que se troca até mesmo de nome". In: BRANDÃO, Junito. Mitologia Grega, Volume I, Editora Vozes, Petrópolis, RJ, 1997. P.54.

70 BACHELARD,Gaston, op., cit, p.61.

71 Idem, p.61.
} 
intimidade terrestre opõe-se a fria e esplêndida expansão celeste. O esquema simbólico fica claro, estrutura-se uma dicotomia entre a realidade interior demoníaca, próxima e sensível, e a idealização exterior distante e impossível, pois que divina. O Demônio é presa do apelo do subterrâneo, que nos termos constantes em Bachelard (1999) representa o retorno ao calidum innatum ${ }^{72}$. À semelhança do mineiro, ele "tem nas veias o fogo interior da terra".

Trata-se de um mergulho vital na interioridade do calor do ser, um feroz resignar-se em si, pois "o fogo é o fenômeno objetivo de uma raiva íntima",73. O Demônio desencadeia assim, uma jornada interior em busca do impossível fogo redentor, e como Empédocles ${ }^{74}$, lança-se no absoluto, na esperança de um improvável retorno ao seu estado divino anterior, no regaço protetor de Deus.

Novamente aqui, ocorre um nítido paralelo da existência humana, enquanto vítima das ardentes paixões mundanas e das incertezas do destino, com o Demônio, em termos do seu drama existencial subterrâneo, resultado do abandono de Deus. Nessa identificação, o Demônio é no homem, tomando emprestada uma imagem poética de Augusto dos Anjos, a "consciência do sátiro que se inferna".

A importância da imagem da integridade do corpo físico na concepção cristã do Além é tamanha, que acaba, paradoxalmente, por obliterar completamente a imagem da alma. Digo isso porque embora o discurso teológico sempre tenha centrado sua escatologia, em termos da salvação última da alma, no amor de Deus, e que todo o drama do cristianismo transcorra em torno da superação metafísica do corpo terreno, criou-se uma necessidade imaginária e popular de representar esse mesmo corpo de forma duradoura nos espaços do Além. Tanto é que mesmo nas representações da arte, até o século XIX, a maioria dos corpos danados no Inferno se mostram, embora atormentados por toda espécie de castigos, inteiros, normais e esteticamente belos. O programa iconográfico das representações da ressurreição estabelece uma recuperação corporal geral e extensiva a todos os ressuscitados, independente dos seus destinos, se Paraíso ou Inferno. Segundo

\footnotetext{
72 Ibidem, p. 62.

73 Ibidem, p. 55.

${ }^{74}$ Empédocles, c. 490 -c. 435 a.c. - Filósofo, naturalista, poeta e homem de estado, combinou o estudo cientifico com uma religião mística do tipo órfico. Nasceu em Agrigento, colônia dórica da Sicília, e faleceu em lugar incerto sob circunstâncias misteriosas. Reza a lenda que ele, incógnito, teria cometido suicídio se atirando na cratera flamejante do Etna para se fundir no puro elemento do vulcão. Aspirava, segundo a tradição, a um endeusamento posterior. $\mathrm{O}$ segredo foi descoberto mais tarde quando uma das erupções vulcânicas expeliu suas sandálias de bronze.
} 
Cousté, "Para o cristão, a salvação coincidirá com a ressurreição do corpo restaurado em seu estado 'glorioso' anterior à falta original'. 75

Até aqui, tudo bem. Mas o que dizer do corpo danado que nas representações da arte se precipita no grande abismo e que permanece com sua aparência normal, a mesma da ressurreição, que mantém a sua coesão corporal, e que fora a expressão facial de dor, possui a mesma integridade física e beleza do corpo abençoado do Paraíso?

\section{REFERÊNCIAS BIBLIOGRÁFICAS}

ARNHEIM, Rudolf. The Split and the Structure: Twenty Essays. University of California Press, 1996.

BACHELARD,Gaston. A Psicanálise do Fogo, São Paulo, Martins Fontes, 1999.

BARNES, Bernardine. Michelangelo's Last Judgement: The Renaissance Response, Berkeley,University of California Press, 1998.

BERNARDINE, Ann Barnes. Michelangelo's Last Judgement: the Renaissance Response. University of California Press, 1998.

BRANDÃO, Junito. Mitologia Grega, Volume I, Editora Vozes, Petrópolis, RJ, 1997.

CLARK, Kenneth. $\mathrm{O} N u$, Um Estudo sobre o Ideal em Arte, Lisboa, Editora Ulissea, 1956.

Ezequiel (37,6), Bíblia Sagrada, Edição Barsa, 1965.

FERRO, Sergio. Michelangelo, São Paulo, Palavra e Imagem, 1981.

GOMBRICH, Ernst H. Arte e Ilusão. Um estudo da psicologia da representação pictórica, São Paulo, Martins Fontes, 1986.

HOLLANDER, Anne. Seeing Trough Clothes, New York, Penguin Books, 1978

LINK, Luther. O Diabo, A Máscara sem Rosto, São Paulo, Editora Schwarcz, 1998

LORENZI, Lorenzo. Devils in Art, Florence, from the Middle Ages to the Renaissance. Florença, Centro Di della Edifími srl, 1997.

LUCIE-SMITH, Edward. Sexuality in Western Art, London, Thames and Hudson, 1995

MINOIS, Georges. História dos Infernos, Lisboa, Teorema, 1997.

75 COUSTÉ, Alberto. A Biografia do Diabo, Rio de Janeiro, Record, 1996, p. 183. 
MORGAN, Genevieve. The Devil, San Francisco, Chronicle Books, 1996.

PETHERBRIDGE, Deanna. The Quick and the Dead, University of California Press, 1997.

RIESS, Jonathan B. Luca Signorelli, The San Brizio Chapel, Orvieto, George Braziller, Inc., New York, 1995.

SCHMITT, Jean-Claude \& Jacques Le Goff. In: Dicionário Temático do Ocidente Medieval, Bauru, Editora da Universidade do Sagrado Coração, 2002.

TREVISAN, Armindo. O Rosto de Cristo: A Formação do Imaginário e da Arte Cristã, Porto Alegre, Editora Age, 2003.

TURNER, Alice. The History of Hell, New York, Harvest Book, 1995. 